OAK RIDGE

NATIONAL LABORATORY

ORNL/TM-2005/172

MANAGED BY UT-BATTELLE

FOR THE DEPARTMENT OF ENERGY

\title{
Evaluation of the Ecological Management and Enhancement Alternative for Remediation of the K1007-P1 Pond
}

\author{
M. J. Peterson \\ R. A. Efroymson \\ M. G. Ryon \\ J. G. Smith \\ G. R. Southworth \\ A. J. Stewart
}

September 2005

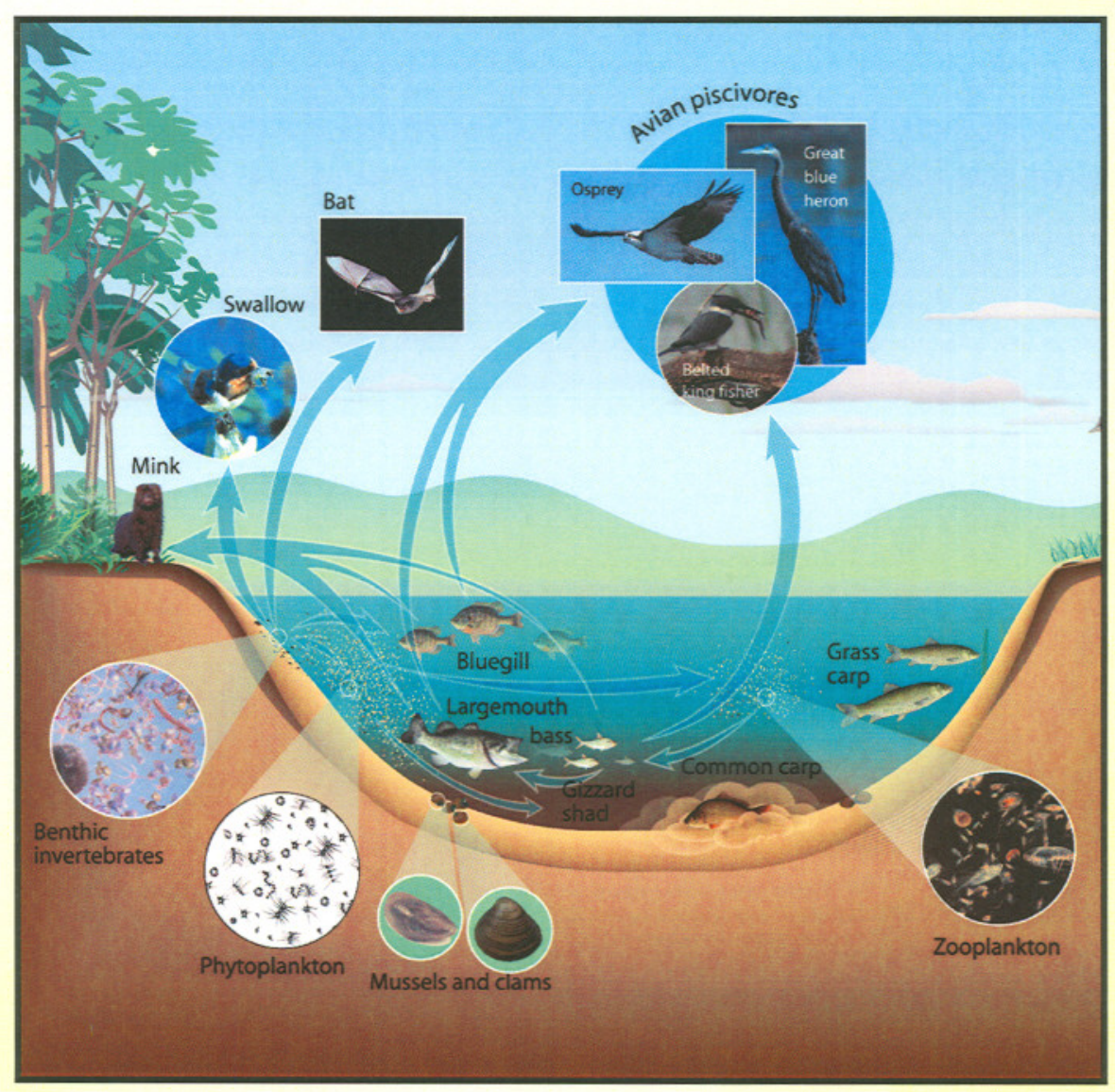

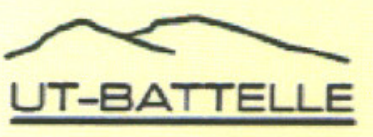

ORNL-27 (2-03) 


\title{
DOCUMENT AVAILABILITY
}

Reports produced after January 1,1996, are generally available free via the U.S. Department of Energy (DOE) Information Bridge:

Web site: http://www.osti.gov/bridge

Reports produced before January 1,1996, may be purchased by members of the public from the following source:

\author{
National Technical Information Service \\ 5285 Port Royal Road \\ Springfield, VA 22161 \\ Telephone: 703-605-6000 (1-800-553-6847) \\ TDD: $703-487-4639$ \\ Fax: $703-605-6900$ \\ E-mail: info@ntis.fedworld.gov \\ Web site: http://www.ntis.gov/support/ordernowabout.htm
}

Reports are available to DOE employees, DOE contractors, Energy Technology Data Exchange (ETDE) representatives, and International Nuclear Information System (INIS) representatives from the following source:

Office of Scientific and Technical Information

P.O. Box 62

Oak Ridge, TN 37831

Telephone: 865-576-8401

Fax: 865-576-5728

E-mail: reports@adonis.osti.gov

Web site: $\mathrm{http}: / /$ www. osti.gov/contact.html

This report was prepared as an account of work sponsored by an agency of the United States Government. Neither the United States government nor any agency thereof, nor any of their employees, makes any warranty, express or implied, or assumes any legal liability or responsibility for the accuracy, completeness, or usefulness of any information, apparatus, product, or process disclosed, or represents that its use would not infringe privately owned rights. Reference herein to any specific commercial product, process, or service by trade name, trademark, manufacturer, or otherwise, does not necessarily constitute or imply its endorsement, recommendation, or favoring by the United States Government or any agency thereof. The views and opinions of authors expressed herein do not necessarily state or reflect those of the United States Government or any agency thereof. 


\title{
EVALUATION OF THE ECOLOGICAL MANAGEMENT AND ENHANCEMENT ALTERNATIVE FOR REMEDIATION OF THE K1007-P1 POND
}

\author{
M. J. Peterson \\ R. A. Efroymson \\ M. G. Ryon \\ J. G. Smith \\ G. R. Southworth \\ A. J. Stewart ${ }^{1}$ \\ Environmental Sciences Division \\ Oak Ridge National Laboratory
}

Date Published: September 2005

\author{
Prepared for \\ J. Pfeffer
}

Bechtel Jacobs Company, LLC

Oak Ridge, Tennessee 37831-7293

\author{
Prepared by \\ OAK RIDGE NATIONAL LABORATORY \\ P.O. Box 2008 \\ Oak Ridge, Tennessee 37831-6285 \\ managed by \\ UT-Battelle, LLC \\ for the \\ U.S. DEPARTMENT OF ENERGY \\ under contract DE-AC05-00OR22725
}

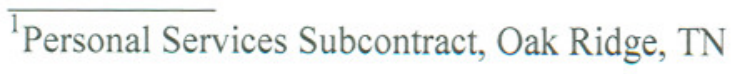





\section{CONTENTS}

Page

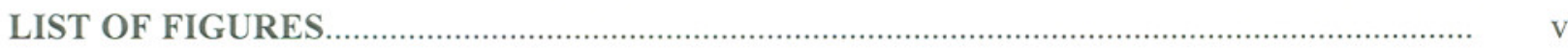

LIST OF TABLES........................................................................................................... vii

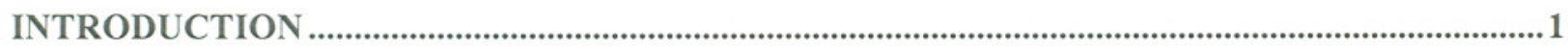

BACKGROUND

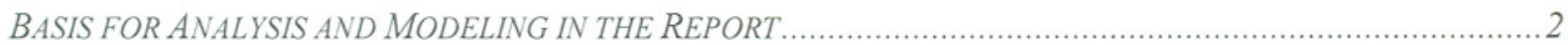

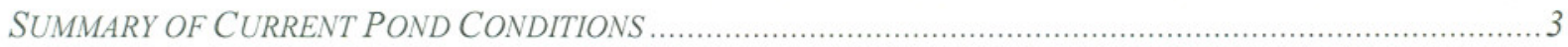

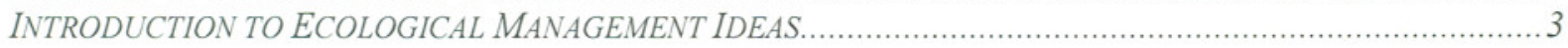

PROPOSED ECOLOGICAL MANAGEMENT ACTIONS...................................................................... 4

DIRECT REMOVAL OF PCB CONTAMINATED FISH (PATHWAY INTERDICTION) .......................................... 4

POND MANIPULATION TO ESTABLISH A NEW STEADY STATE THAT MINIMIZES PCB BIOACCUMULATION........ 4

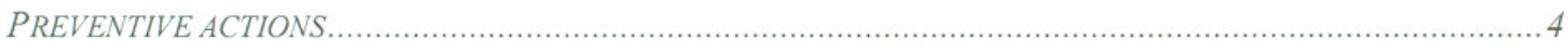

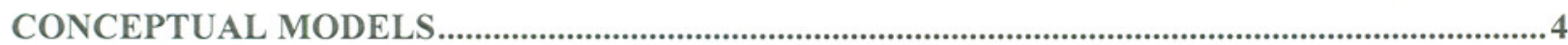

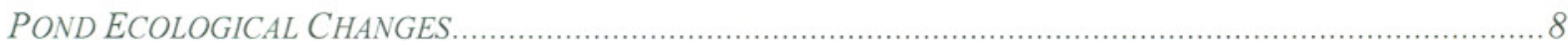

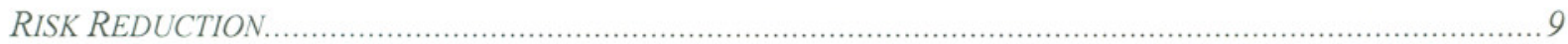

PCB FATE IN THE AQUATIC ENVIRONMENT ….....................................................................10

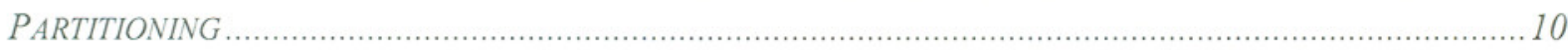

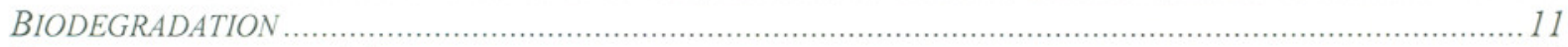

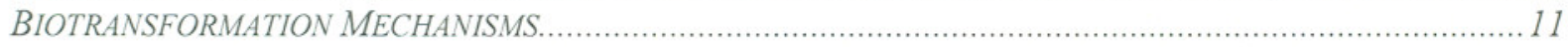

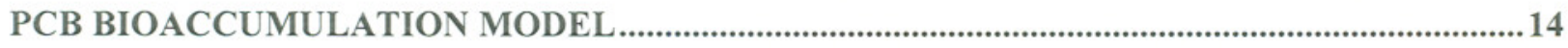

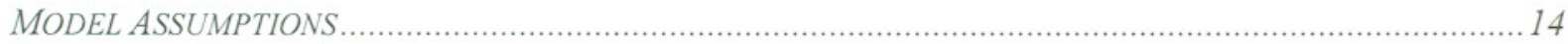

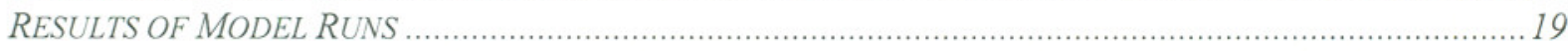

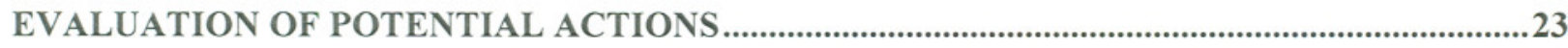

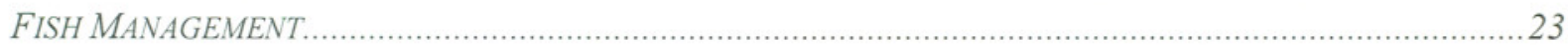

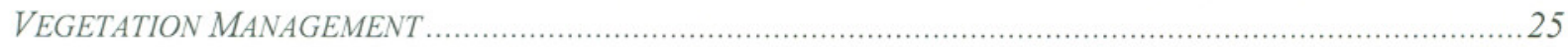

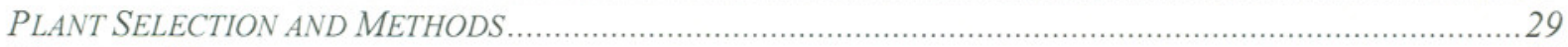

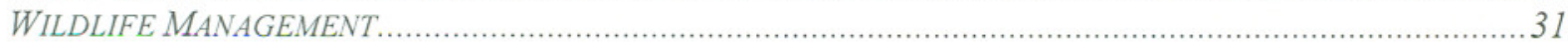

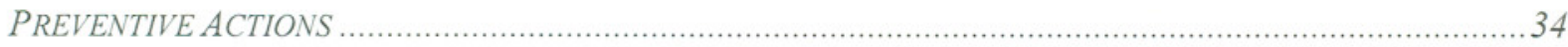

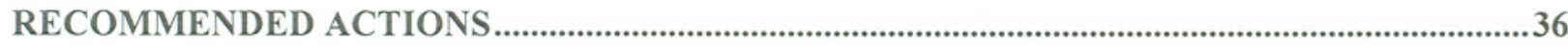

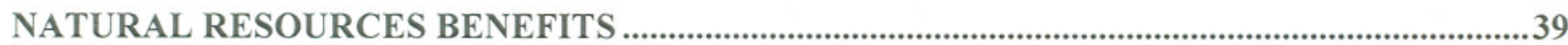

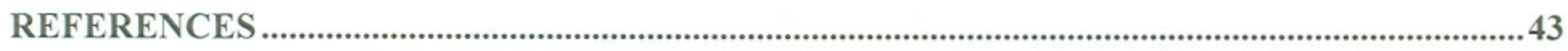

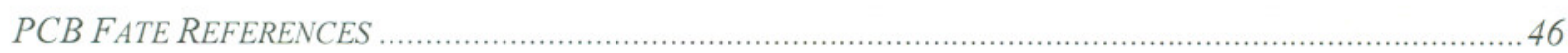

APPENDIX A. VALIDATION OF POND ASSUMPTIONS …….............................................. A-1

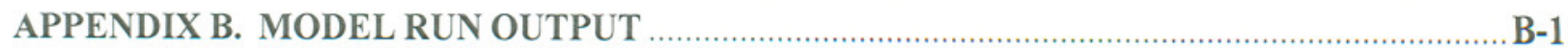





\section{LIST OF FIGURES}

Figure $\quad$ Page

1 Map showing the P1 through P5 Ponds near the East Tennessee Technology Park .............. 2

2 A conceptual model depicting structural and process changes to the P1 Pond under the Ecological Management alternative .................................................................................... 5

3 A conceptual model depicting the current food web of the P1 Pond ................................... 6

4 A conceptual model depicting the food web under the Ecological Management alternative

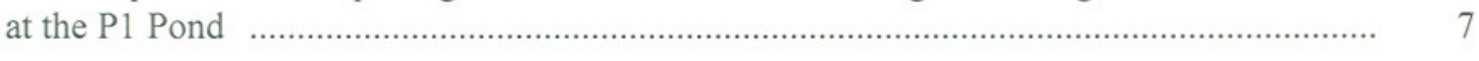

$5 \quad$ Variation in estimated BAF of largemouth bass in P1 Pond with fish weight ....................... 17 



\section{LIST OF TABLES}

Table

Page

1 Values of input variables used in the steady-state PCB bioaccumulation model .................. 18

2 Output of steady-state PCB transport model under various treatment actions at P1 Pond .......

3 Trophodynamic properties of pond ecosystems in which primary production is dominated by planktonic algae versus submersed and emergent rooted aquatic macrophytes.

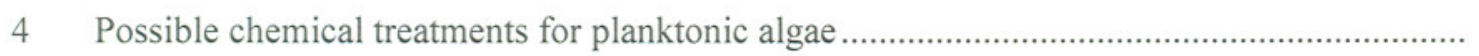

5 Habitat valuation results for current and future conditions estimated for 50 years following implementation of the Ecological Management alternative 


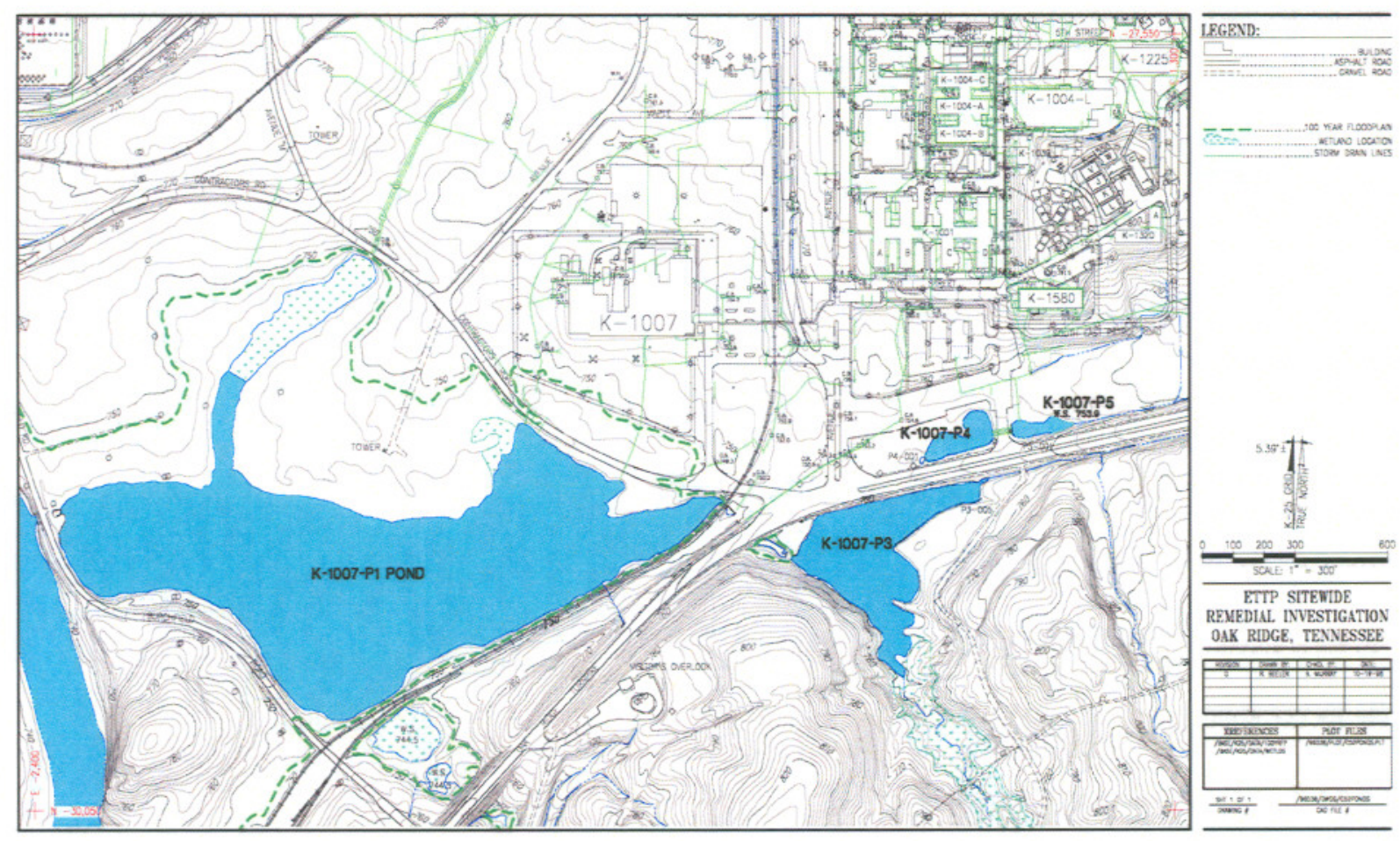

Fig, z1.18. K-1007-P Pands Removal Action sediment sample locations

Fig. 1. Map showing the P1 through P5 Ponds near the East Tennessee Technology Park. Map from the ETTP Site Wide Remedial Investigation and courtesy of BJC.

\section{BACKGROUND}

\section{Basis for Analysis and Modeling in the Report}

An evaluation of the human and ecological risks associated with the P1 Pond and surrounding environs was conducted as part of the ETTP Site-Wide Remedial Investigation. The RI provides the basis for the focus on PCBs as the most important unacceptable risk to human and ecological health in the pond. Other P1 contaminants, media, or pathways of risk to receptors are identified in the RI, but are not addressed as a major risk reduction goal for the ETTP Site-Wide Feasibility Study. Therefore, the goal of the Ecological Management alternative is to reduce unacceptable risks associated with PCBs in fish. Many of the actions proposed for this alternative, however, are likely to reduce risks associated with other contaminants and their pathways.

The high PCB concentrations in fish from the P1 Pond are most certainly due in part to the current ecological condition of the pond that maximizes PCB biomagnification. This basic assumption and the factors contributing to it were evaluated by conducting an intensive field study of the P1 Pond in the summer of 2004 (for a thorough presentation of current P1 Pond biological conditions, see Peterson et al. 2005). Major hypotheses regarding the P1 Pond's current fish community, PCB fate and transport processes, pond vegetation, and limnological conditions that contribute to the high PCB levels in fish were validated by the study (Appendix A). The results of the 2004 ecological assessment, in concert with longterm datasets obtained as part of the ETTP Biological Monitoring and Abatement Program (BMAP) and recent abiotic sampling for the RI, provide the basis for the assessment of current conditions. 


\section{Summary of Current Pond Conditions}

The current P1 Pond condition is described in more detail in previous reports as well as the Conceptual Model and PCB Bioaccumulation Sections of this report. Briefly, the assemblage of the fish community in the P1 Pond, in particular four species, contributes to the PCB bioaccumulation problem there. Largemouth bass and gizzard shad are problem species due to their high affinity for accumulating PCBs and because they are readily consumed by human (in the case of bass) and ecological (in the case of shad) receptors. Grass carp and common carp (as well as shad) contribute to the problem in the P1 Pond because of the way they alter the habitat and water quality conditions in the pond. Foraging activities by non-native grass carp and common carp have contributed to the near absence of rooted vegetation (submerged and emergent) in the pond, resulting in high biomass of suspended algae, flocculent sediments, and open water conditions that are highly desirable for gizzard shad. Shad are sediment/algae eaters that are high in oily tissue (PCBs are highly lipophilic), can accumulate very high levels of PCBs, and are a favorite prey item for largemouth bass. The largemouth bass in the P1 Pond, feeding on the high numbers of available shad, grow to a large size and have relatively high lipid content. As a result of the unique attributes of the fish populations in the pond and PCB biomagnification processes, largemouth bass in the P1 Pond contain very high levels of PCBs (on average $>10 \mathrm{mg} / \mathrm{kg}$ ), as do gizzard shad. Largemouth bass are an important game fish species and are a potential risk to human health, while gizzard shad are an abundant prey item for terrestrial and avian piscivores.

\section{Introduction to Ecological Management Ideas}

Various components of the proposed Ecological Management strategy have been routinely applied as part of fisheries management principles, where manipulation of fish populations is a common occurrence. Other elements of this strategy are more akin to vegetation management or landscaping ideas. The term "biomanipulation" is not new and in the broadest terms indicates the management of aquatic communities by controlling natural populations of organisms to produce desired conditions (Petr 2000). Biomanipulations similar to those proposed here have been conducted in the United States and many other countries, including those focused on removal of fish from shallow lakes in an effort to encourage "cascading impacts" that enhance water clarity, stimulate macrophytes, and establish a new steady state.

Hansson et al. (1998) in a review article of previous biomanipulations, concludes that not only is biomanipulation possible, but is a relatively inexpensive and attractive method for management of eutrophic lakes. Based on large-scale manipulations, Hansson et al. (1998) provides the following recommendations: (1) the reduction in the biomass of planktivorous fish should be $75 \%$ or more; (2) the fish reduction should be performed efficiently and rapidly (within 1-3 years); (3) efforts should be made to reduce the number of benthic feeding fish; (4) the recruitment of young-of-the-year fish should be reduced; (5) the conditions for establishment of submersed macrophytes should be improved; and (6) the external input of nutrients (phosphorus and nitrogen) should be reduced as much as possible before the biomanipulation. Each of these recommendations is addressed, as well as site-specific actions to enhance pond ecological conversion and reduce PCB risks, as part of the Ecological Management alternative (described in detail in the following sections).

The considerable influence of nonnative grass carp on pond/lake vegetation, water quality characteristics, and food web changes, is well known. A review of the many studies of the effects of grass carp is presented in a United Nations Technical Paper (Petr 2000). The P3 Pond provides a nearby example of dramatic changes in pond ecological conditions as a consequence of the presence of grass carp. For many years the P3 Pond was covered with water lilies and other emergent vegetation. In the late $1980 \mathrm{~s}$ at the request of K-25 management, grass carp were introduced into the pond (as well as all the other P Ponds) to control the vegetation. Within a short time all vegetation was eaten by the grass carp, 
and the ponds remained denuded of rooted vegetation with colored water indicative of phytoplankton dominance until approximately 2003-2004, when presumably the grass carp died out. Currently P3 is vegetated along most of the shoreline (although with nonnative and less desirable plant species), with clear water and multiple bluegill spawning beds evident. P3 still likely contains largemouth bass and common carp in small numbers, but it does provide a small-scale example of how fish community changes can enhance certain characteristics that are deemed desirable in reducing risks at the P1 Pond.

\section{PROPOSED ECOLOGICAL MANAGEMENT ACTIONS}

The feasibility of the Ecological Management and Enhancement alternative to P1 Pond remediation was evaluated by considering a number of management actions that directly reduce risk, and prevent reoccurrence of risk. Many of these actions have a secondary benefit in that they enhance natural resources benefits, but no action is proposed for this alternative unless it will help to reduce risks. Ecological Management actions proposed for this alternative can be divided into three major components:

\section{Direct removal of PCB contaminated fish (pathway interdiction)}

- Remove all largemouth bass (ending PCB human health risk from this primary game fish)

- Remove all gizzard shad (ending PCB ecological risk from this primary forage fish)

\section{Pond manipulation to establish a new steady state that minimizes PCB bioaccumulation}

- Remove grass carp (that eat aquatic vegetation)

- Remove common carp and other undesirable fish species (that resuspend sediment)

- Apply algaecide and chemical treatment to decrease phytoplankton and nutrient availability and encourage growth of rooted plants

- Grade pond bank to a more gradual slope to facilitate the establishment of plants

- Plant aquatic macrophytes

- Plant riparian vegetation to limit soil surface erosion and nutrient inputs, as well as limit shore use by geese

- Addle goose eggs and add flag lines to reduce habitat quality for Canada geese that contribute to the high nutrient loading to the pond

- Stock bluegill to push system to a stunted small-fish population

\section{Preventive actions}

- Add asphalt to Burchfield Road as a barrier to fish movement from Poplar Creek

- Remove undesirable fish from upstream areas (P3-P5)

- Construct fence-line between the revegetated area around the pond and the remaining narrow grassy area to discourage geese from visiting the pond

- Establish vegetation to help ensure pond conditions cannot revert to previous conditions

\section{CONCEPTUAL MODELS}

A good conceptual model is a critical component of any risk reduction strategy. Conceptual models may be constructed from several perspectives, and include activity models, which depict the consequences of an environmental activity, site models, which depict the features of a site that determine its response to an activity, and receptor models, which focus on processes affecting the abundance, reproduction, or other property of an organism, population, or community (Suter 1999). Two types of 
conceptual models are presented here. The first is an activity model showing how management actions are expected to affect the structure and function of the P1 Pond (Fig. 2). An additional food web model (a type of site model) shows, in a more pictorial manner, how PCB concentrations and biological structure of the pond are expected to be affected by the management actions. Figures 3 and 4 depict the primary components of the current and proposed future P1 Pond food webs, respectively.

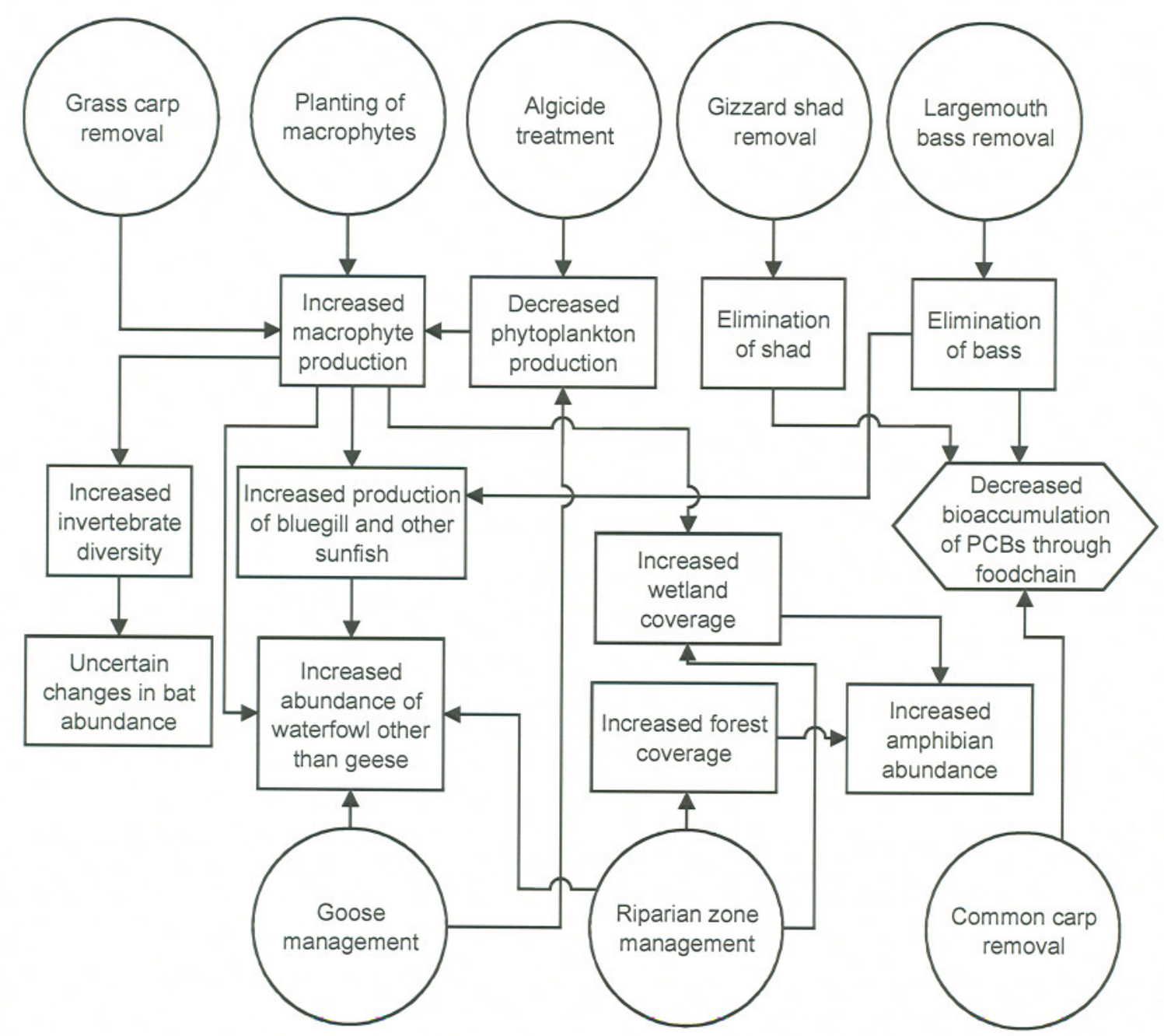

Fig. 2. A conceptual model depicting structural and process changes to the P1 Pond under the Ecological Management alternative. Circles represent management actions, rectangles are states, and hexagons are processes. Goose management includes addling goose eggs, adding flag lines, and constructing a goose-detering fence line. Riparian zone management includes planting trees and grading banks.

The conceptual models presented here are discussed in the following two subsections highlighting (1) pond ecological changes, and (2) risk reduction. 


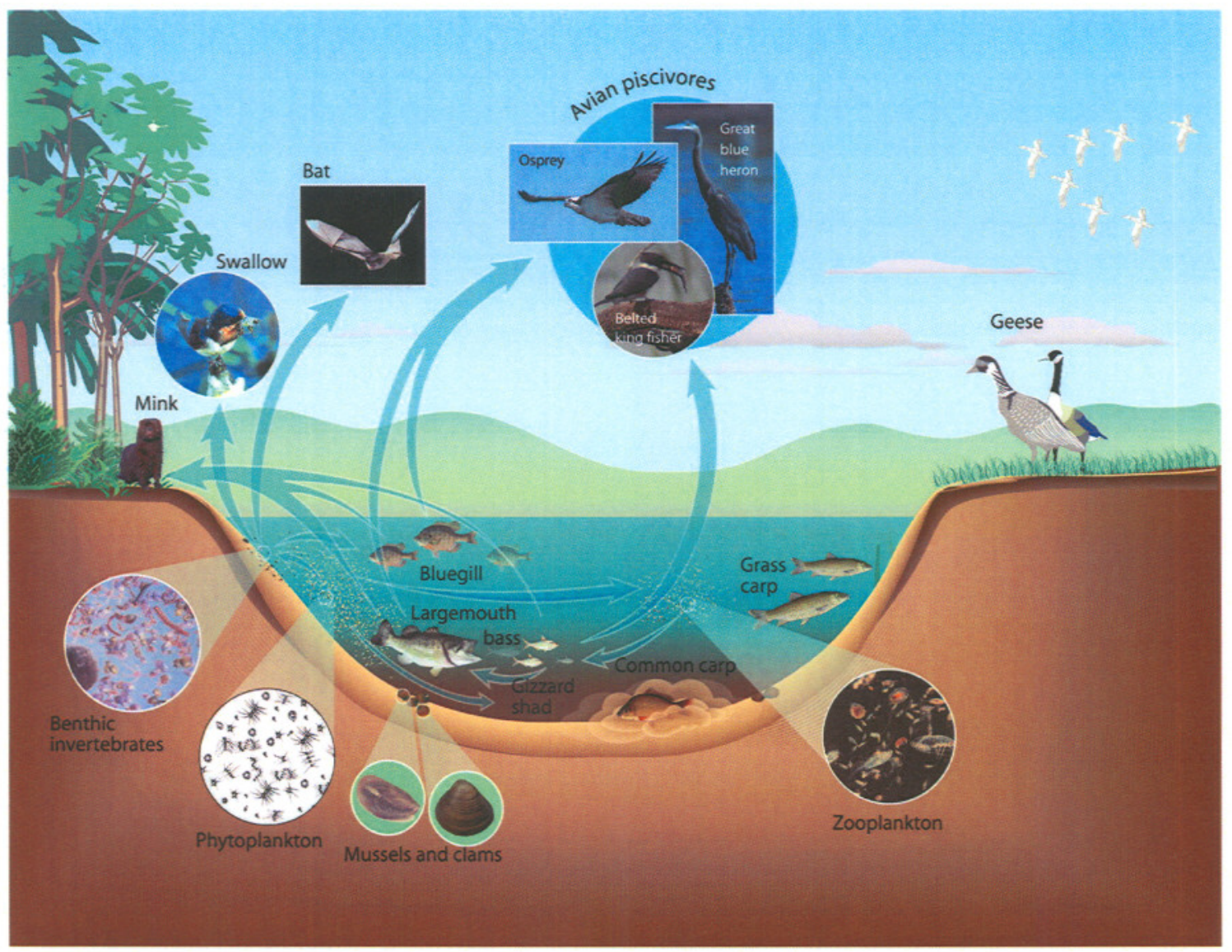

Fig. 3. A conceptual model depicting the current food web of the P1 Pond. Arrows point from forage or prey to consumers; arrows also represent the pathways of PCBs and other chemical contaminants. The predominant aquatic food chains begin with phytoplankton, include benthic and planktonic invertebrates, and end with largemouth bass. Piscivorous wildlife and insectivores are also present. 


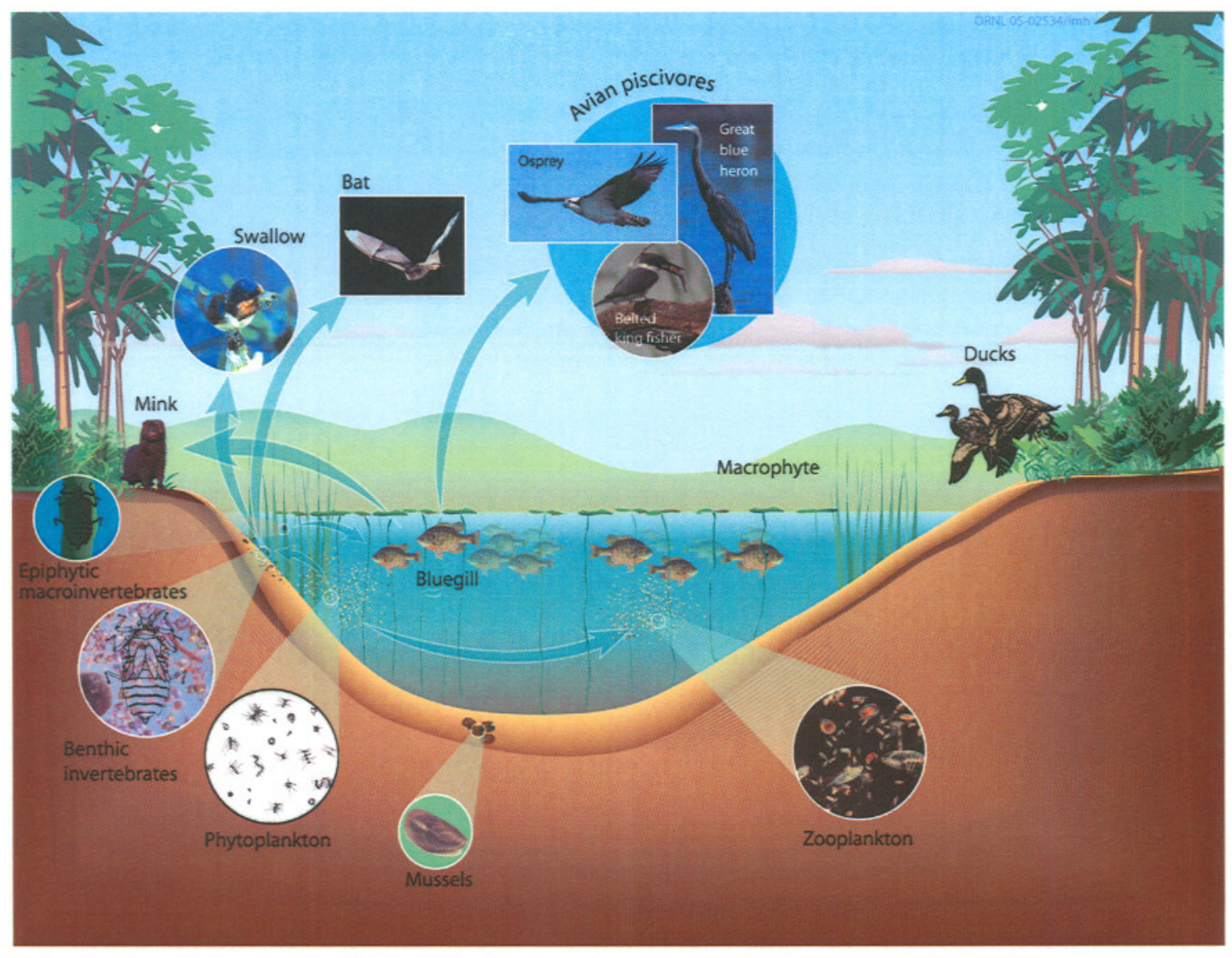

Fig. 4. A conceptual model depicting the food web under the Ecological Management alternative at the P1 Pond. Arrows point from forage or prey to consumers. The predominant aquatic food chain is from macrophytes to epiphytic invertebrates to bluegill. Largemouth bass and gizzard shad are absent. Piscivorous wildlife and insectivores are present. 


\section{Pond Ecological Changes}

The major effects on the food web expected under the Ecological Management alternative include the following, which are shown in Fig. 2 and the difference between Figs. 3 and 4:

(1) removal of largemouth bass, the top predator, to reduce the length of the primary food chain;

(2) removal of gizzard shad, a lipid-rich forage fish;

(3) removal of grass carp, thus allowing emergent and submersed macrophytes to become established;

(4) removal of common carp and other fish that disturbance sediments (helping to reduce phytoplankton and increase macrophyte growth);

(5) replacement of phytoplankton with emergent and submersed macrophytes (or their attendant attached algae) as the principal primary producers;

(6) attachment of periphyton and epibenthic insects to macrophytes; and

(7) temporary removal of all clams and long-term reduction of clam numbers due to a reduction in phytoplankon.

In the current food web, nutrients enter the pond from storm drains and overland flow over gooseimpacted areas. Grass carp curtail macrophyte growth, so nutrients are quickly taken up by suspended algae (phytoplankton). Open-water, filter-feeding gizzard shad consume suspended materials (including phytoplankton, small zooplankton, clay, and organic detritus) as well as sediment detritus. Carp and gizzard shad resuspend PCB-contaminated sediments in foraging, allowing a fraction of the particleassociated PCBs to redissolve in the water. Shad are consumed by largemouth bass and are preferred prey for osprey and possibly herons (and potentially humans, as this species is a much sought-after game fish; Fig. 4). With an abundant nutrient base and desirable prey, the largemouth bass in the pond are abundant and grow relatively large, further increasing PCB body burdens and worsening the human health risks associated with the pond (Peterson et al. 2005).

Under the Ecological Management alternative, primary producers will shift from phytoplankton to macrophytes and their attendant periphyton (Figs. 3 and 4). The pond will convert from a hyper-eutrophic to a pond more eutrophic-mesotrophic in characteristics. Greater dominance of macrophytes will help stabilize sediments, removal of common carp and suckers will reduce the amount of bioturbation (and thus PCB redissolution) and increase water clarity, and the improved water clarity will in turn promote macrophyte growth. The food chain will be shortened by the Ecological Management alternative, with no top-level predators and dominance of small sunfish. Macrophyte-dominated ponds of this type are a common steady state, and are difficult to change once established. They are also a common target of fish management practices because they represent poor opportunities for angling.

Bluegill are currently abundant in the P1 Pond and are a species that will be encouraged to dominate upon ecological manipulation. (Even under current $\mathrm{PCB}$ exposures in the pond, bluegill are relatively low in PCBs; Peterson et al. 2005) Under the Ecological Management alternative, the predominant aquatic bluegill food chain would shift from:

$$
\text { phytoplankton } \rightarrow \text { zooplankton } \rightarrow \text { benthic invertebrate } \rightarrow \text { bluegill }
$$

to: $\quad$ macrophyte $\rightarrow$ epiphytic invertebrate $\rightarrow$ bluegill (see Fig. 4).

Bluegill also get a relatively high proportion of their diet from terrestrial invertebrates (that contain little to no PCBs). In the absence of predators, bluegill will increase in number, but achieve a smaller average size (further decreasing PCB concentrations). The relative abundance of bluegill to other sunfish 
is not expected to change under this alternative, with bluegill continuing to be the dominant sunfish in numbers and biomass.

The invertebrate community has not been surveyed at the P1 Pond, but we believe that it consists primarily of midges (chironomids) and oligochaetes. After the manipulation, small, highly mobile invertebrates such as chironomids and other dipterans should repopulate the pond rapidly. Macrophytes will favor increases in the number of dragonflies and damselflies (odonates), which consume smaller invertebrates. The aquatic plants also provide much more surface area for small invertebrates, such as chironomids, chydorid zooplankton, and rotifers. Moreover, the increase in invertebrate diversity is likely to coincide with numerous smaller pulses of emergent insects and a more uniform presence of adult insects through time.

Effects of the Ecological Management alternative on the abundance and diversity of bats are uncertain. The gray bat obtains most of its prey above streams and reservoirs. In two studies, the three main insect components of the diet of Myotis griscens were Lepidoptera, Coleoptera, and Diptera (Best et al. 1997, Lacki et al. 1995). However, bats have been observed to consume prey based on availability (Barclay and Brigham 1994), feeding opportunistically in the months of May and July, eating insects from eleven families and nine orders (Lacki et al. 1995).

Under the Ecological Management Alternative, waterbirds would be expected to increase in diversity and probably abundance. The diversity of wading birds is expected to increase due to discouraging Canada geese and due to grading of the pond banks (Fig. 4). Without bass, the abundance of bluegill should increase, which also will potentially increase the abundance of waterbirds (Fig. 4), as bluegill may be more available in shallow areas than pelagic gizzard shad. However, bluegill are structureoriented fish and may be more difficult for many waterbirds to catch.

\section{Risk Reduction}

Risk management strategies for contaminated sediments focus on removing the contaminated material or interrupting the exposure pathways that lead to ecological or human receptors, i.e., pathway interdiction (Magar et al. 2005b). This is the strategy associated with the Ecological Management alternative is pathway interdiction.

Under the Ecological Management alternative, human health risk is expected to be reduced to a very low probability of low exposure. With largemouth bass removed from the pond, the pond will be less attractive to trespassing fishermen. The remaining sunfish could be of fishable size, but are not viewed as sufficiently attractive to encourage trespassing. Moreover, the macrophyte cover, graded banks, and structure-oriented habitat of bluegill will increase the difficulty of fishing without a boat. If bluegill were occasionally caught, the PCB levels in fillets from the very largest individuals, assuming no change in exposure, would be much lower than current levels in bass and shad $(0.88 \mathrm{mg} / \mathrm{kg}$ was the average in bluegill in 2004; Peterson et al. 2005). The concentrations would be no higher than concentrations in fish adjacent Poplar Creek, and would be over two-fold less concentration than the FDA threshold limit of $2 \mathrm{mg} / \mathrm{kg}$. The expected smaller average size of bluegill, the change in diet, and the stabilization of sediments are all factors that are expected to decrease PCB levels in fish even further from those observed under the current conditions.

Over the long term, additional PCB reductions are possible through the deposition of cleaner sediment and by slow reductive dechlorination (see PCB Fate Section). With the discontinuation of routine use and discharge of bioaccumulative contaminants such as PCBs and chlordane, and the subsequent burial of contaminated sediments with cleaner sediments in downstream reservoirs, PCBs and 
chlordane concentrations have decreased at many sites nationally, including in Watts Bar (DOE 2005). Also, the dechlorination of meta- and para-chlorinated arochlors could result in relative detoxification of a PCB mixture through lower concentrations of coplanar congeners and via the transformation of more toxic, more extensively chlorinated congeners (Mousa et al. 1998, Magar et al. 2005a).

Ecological risk is expected to decrease by at least four mechanisms (Fig. 2): (1) fewer gizzard shad, which accumulate PCBs and other hydrophobic chemicals (dioxins, methyl mercury) through filterfeeding, so their avian predators would accumulate less of these chemicals; (2) fewer or no largemouth bass to accumulate hydrophobic chemicals such as PCBs; (3) removal of common carp and similar species that would otherwise resuspend sediments or disperse resident chemicals (bioturbation); and (4) macrophytes would stabilize sediments and sediment-associated contaminants. Although we predict that $\mathrm{PCB}$ concentrations would be reduced over time even if bass remained in the pond, bass removal immediately reduces risk from this species, allows for more rapid conversion of the pond's ecology to sunfish dominance by removing predation, and shortens the food chain and minimizes biomagnification processes.

The remaining bluegill may still consume some benthic invertebrates, but their diets will increasingly consist of epiphytic macroinvertebrates and relatively uncontaminated terrestrial macroinvertebrates, so their body burdens should be lower compared to present measurements. In addition, the average size of bluegill is expected to be smaller.

Given the changes outlined above, waterbirds will consume prey that is less contaminated. Thus, current risk to piscivorous wildlife from PCB mixtures, dioxin/furans, and mercury that was determined in the Baseline Ecological Risk Assessment (BERA) should be reduced substantially under the proposed alternative. All of these contaminants of ecological concern are hydrophobic and tend to bioaccumulate through many of the same food chain mechanisms as the PCBs, whose uptake was modeled in this alternative assessment.

The BERA concludes that the P1 Pond poses a risk to benthic invertebrates from several chemicals (PCB mixtures, 11 polycyclic aromatic hydrocarbons, chromium, mercury, and nickel). Risk to benthic invertebrates and their consumers (such as swallows, bats, dragonflies, etc.) is not directly addressed by this alternative, except to the extent that deposited, clean sediments will not be resuspended as often if common carp and suckers are absent and macrophytes are present.

\section{PCB FATE IN THE AQUATIC ENVIRONMENT}

The potential for environmental transformation processes and fate of $\mathrm{PCBs}$ were evaluated by literature review (PCB Fate references are listed separately in the reference list). The focus of the following discussion is on processes that may be relevant to the P1 Pond.

\section{Partitioning}

PCBs that enter water sorb to organic particles in the water column and deposit in sediments, especially fine-grained, organic rich sediments. Concentrations of PCBs in Hudson River sediments have decreased since the late 1970 s, primarily because of deposition of additional cohesive solids with lower PCB concentrations, rather than because of dechlorination (Connolly et al. 2000). Sorbed PCBs are susceptible to settling, resuspension, and burial. Bioturbation can substantially affect the distribution of PCBs in sediments (Schaffner et al. 1997). The biologically active sediment layer is the top $5-10 \mathrm{~cm}$, which is mixed by benthic organisms and is continually in contact with overlying water. PCBs, especially less chlorinated species, move from noncohesive sediments to the water column, another pathway by 
which PCB concentrations decrease in sediments (Connolly et al. 2000). Dissolved PCBs that are not associated with colloidal materials are also subject to volatilization. More chlorinated congeners volatilize from water during warmer seasons, and less chlorinated congeners volatilize year-round. The most important predictor of volatilization rate in the Hudson River was the concentration of PCBs in the top $0.5 \mathrm{~m}$ of water (Commoner et al. 2000). Moreover, PCBs can volatilize much more significantly if sediments are dried (Chiarenzelli et al. 1996), which has relevance to the potential draining of the P1 Pond. In addition to relative susceptibilities to transport, changes in the distribution of congeners in sediments can result from biotransformation (Karcher et al. 2004).

\section{Biodegradation}

The primary environmental transformation processes for PCBs are biotransformations, i.e., anaerobic microbial dechlorination, aerobic microbial degradation, or metabolism by organisms that take up PCBs. Few articles are available on the photolysis of PCBs, and these tend to involve studies of PCBs in air (Sinkkonen and Paasivirta 2000), accelerating the process with laboratory lamps and sensitizers such as amines, because natural rates of photodegradation are very slow due to the low intensity and lack of short wavelength radiation (Lin et al. 1995).

\section{Biotransformation Mechanisms}

Chemistry. There are 209 PCB congeners and all have different potentials for dechlorination and biodegradation. Compounds with fewer chlorine atoms are generally more susceptible to aerobic transformation, while those with more chlorine atoms are more readily transformed anaerobically. Moreover, the placement of chlorine atoms is a factor in determining degradation rate. PCB congeners with the chlorine in the meta or para positions are more easily transformed than compounds with the chlorine attached to the ortho carbon.

Aerobic transformation of PCBs occurs via a mechanism similar to aerobic transformation of the biphenyl molecule, but only PCBs with relatively few chlorine atoms are very susceptible. The ring is oxidized by a 2,3-dioxygenase, which results in hydroxyl groups at adjacent ortho and meta positions. [A 3,4-dioxygenase may also act on these molecules (Bedard and Haberl 1990, Brown et al. 1984).] Then the ring is cleaved by the action of another dioxygenase, followed by further metabolism. If PCB congeners contain several chlorine groups, especially in the 2 (ortho) or 3 (meta) position, the first oxygenation of a PCB may be blocked.

In contrast, highly chlorinated PCBs are most susceptible to anaerobic biotransformation, termed reductive dehalogenation because of the substitution of chlorine atoms with hydrogen (Tiedje et al. 1993). The PCB molecule serves as the electron acceptor. Dehalogenation can occur as co-metabolism, in which enzymes are designed for other processes, or dehalorespiration or halorespiration, in which microorganisms use halo-organics as electron acceptors in energy metabolism. Reductive dehalogenation generally requires the presence of other organic matter, such as decaying vegetation, to provide the required electron donor.

Dehalogenation of meta chlorines is favored, followed by para, and followed by ortho chlorines, though some sediments primarily remove meta chlorines, others remove para chlorines, and still others remove both (Tiedje et al. 1993). Whereas congeners with chlorine atoms in the meta and para but not ortho positions can be dehalogenated under certain conditions to biphenyl, those with chlorine atoms in the ortho position are probably not fully dechlorinated by reductive dehalogenation. Therefore, complete dehalogenation of congeners in typical PCB formulations has not been observed. However, even partial anaerobic PCB dechlorination results in a reduction of toxicity because the highly toxic coplanar PCBs (with chlorine only in meta and para positions) are most readily biodegraded. 
Rates and Extents of Biotransformation of PCBs. Rates of biotransformation are generally directly proportional to solution concentrations rather than total concentrations in sediment (Zwiernik et al. 1999), though Sokol et al. (1998) found that above concentrations of 35 to $45 \mathrm{mg} / \mathrm{kg}$, the dechlorination rate of Aroclor 1248-spiked St. Lawrence River sediments was proportional to concentration in sediment. Because solution concentrations for most congeners are in the low nanogram per liter concentration, transformation rates can be very low.

Sinkkonen and Paasivirta (2000) reviewed estimated half-lives for PCBs in a few different environments. However, the reader should be cautioned that the concept of half-life is only appropriate if transformation is a first-order process and unaffected by changes in PCB bioavailability, microbial growth, or nutrient availability. In Hudson River sediments penta- and tetrachlorinated PCBs are decreasing with half-lives of about 10 years (Brown et al. 1984). PCB 105, PCB 126, PCB 156, and PCB 169 in the anaerobic Ketelmeer sediment in the Netherlands were estimated to have half-lives of nine years (Beurskens et al. 1993). PCBs in New Bedford Harbor sediments had dechlorination half-lives of 465 years and 13 years for dechlorination of two 15 -to- 17.5 -cm sediment samples containing PCB 31 , and 7.5 years and 4.4 years for two samples containing PCB 105. Half-lives for dechlorination of PCB 118 and PCB 153 in New Bedford Harbor sediments were 6.8 years and 18.8 years, respectively (Lake et al. 1992).

Factors that may affect rates of transformation include concentration of PCBs and individual congeners, bioavailability of $\mathrm{PCBs}$, the presence of inhibitors, temperature, nutrient concentrations, the number of dechlorinating microorganisms, and the presence of electron donors and competing electron acceptors (Tiedje et al. 1993). Most of these factors affect the composition and activities of the microbial community, and therefore, the rate and extent of decholorination (Wiegel and Wu 2000). Rates of dechlorination have been observed to be a linear function of PCB concentrations in sediment (Rhee et al. 2001, Cho et al. 2002), at least above the threshold concentrations described below. The presence of residual petroleum in sediments often provides a nonaqueous phase analogous to organic matter that lowers solution concentrations of PCBs and rates of dechlorination (Zwiernik et al. 1999). The rate of dechlorination is closely related to the population growth of dechlorinating microorganisms (Rhee et al. 2001). Although aging sometimes affects the bioavailability and transformation rates of organic compounds, the dechlorination of PCBs aged in sediments occurs at rates similar to those in freshly spiked sediments (Abramowicz et al. 1993).

Sokol et al. (1998) argue that "a major controlling factor for natural remediation potential in sediments is the initial PCB concentration that determines the maximum extent of dechlorination rather than the dechlorination rate." They observed a threshold for dechlorination at concentrations at about 35 to $45 \mathrm{mg} / \mathrm{kg}$, with reactions not occurring below those concentrations. Similarly, Cho et al. (2003) found PCB congeners in St. Lawrence River sediment slurries that were dechlorinated only if initially present at concentrations above $40 \mathrm{mg} / \mathrm{kg}$, others that were dechlorinated at concentrations above $60 \mathrm{mg} / \mathrm{kg}$, and less chlorinated congeners that increased in concentration. [However, it is remarkable that final concentrations of congeners were significantly lower than threshold values (Cho et al. (2003).] Based on a larger group of studies, reviews of PCB biotransformation have estimated this possible general threshold at $50 \mathrm{mg} / \mathrm{kg}$ (Tiedje et al. 1993), but one of these reviews suggests that dehalogenation might continue at lower PCB concentrations if cometabolism is involved and food for dehalogenating organisms is available. In this case, rates would be slow and difficult to measure, but perhaps significant over multi-year periods. Similarly, Sokol et al. (1998) cite studies where dechlorination occurred at PCB concentrations as low as $10 \mathrm{mg} / \mathrm{kg}$ sediment and possibly in the ppb range, with bioavailability suggested as the explanation for different thresholds at different sites. PCB dechlorination at Lake Hartwell, SC, apparently occurs at sediment concentrations much lower than $50 \mathrm{mg} / \mathrm{kg}$ (Magar et al. 2005b). It has also been suggested that 
the yields of PCB-dechlorinating microorganisms are reduced at very high concentrations of PCBs (e.g., above $200 \mathrm{mg} / \mathrm{kg}$, Rhee et al. 2001).

Effects of Eutrophication. Koelmans et al. (2001) reviewed potential interactions between eutrophication and the fate and effects of organic contaminants. Implicit in most research are the assumptions that "changes in trophic state caused negligible feedback on toxicant fate and effects" and "toxicity produced negligible feedback on physiochemical processes that determined fate" (Koelmans et al. 2001). However, eutrophication can cause partitioning to and dilution of contaminants within increasing biomass, contaminant sorption to increasing dissolved organic carbon, increasing sedimentation of contaminants, altered biotransformation based on increased nutrients, and increasing bioaccumulation in the food chain (Koelmans et al. 2001), and nutrient removal can cause the opposite effects.

Case Study: Lake Hartwell, SC. The most relevant measurements of PCB reduction to the P1 Pond are probably those taken at Lake Hartwell near Clemson in Pickens County, SC, a U.S. Army Corps of Engineers reservoir system on the state line between South Carolina and Georgia on the Savannah, Tugaloo, and Seneca Rivers. This is the only site where measurements of dechlorination have been taken in the field rather than in laboratory microcosms (Magar et al. 2005b). Also, the southeastern regional location of this reservoir suggests its relevancy to the P1 Pond with respect to climate and possibly soils. However, this lake is 22,660 ha in area, compared to the 10 ha of the P1 Pond, the major source of PCBs at Lake Hartwell has been closed since 1978, and the sedimentation rate of $2 \mathrm{~g} / \mathrm{cm}^{2} / \mathrm{yr}$ (Magar et al. 2005a) is probably significantly higher than sedimentation at the P1 Pond. As of 2003, Lake Hartwell was the only location in the United States where monitored natural attenuation was chosen as a remedy for PCBcontaminated sediment (Pakdeesusuk et al. 2003). The cleanup goal is $1.0 \mathrm{mg} / \mathrm{kg} \mathrm{PCBs}$ in the surface $5 \mathrm{~cm}$ (Brenner et al. 2004) or $10 \mathrm{~cm}$ (Magar et al. 2005b) of sediment.

Substantial reduction in PCB concentrations has occurred because of gradual burial of contaminated sediments by cleaner sediments. During a 25 -year period, peak concentrations in sediments have decreased from 10 to $66 \mathrm{mg} / \mathrm{kg}$ in buried sediments, to 1 to $3 \mathrm{mg} / \mathrm{kg}$ in surface sediments (Brenner et al. 2004). Pakdeesusuk et al. (2003) measured dechlorination rates in sediments of Lake Hartwell. Maximum rates, measured in microcosms ranged from 0.29 to $0.87 \mu$ g-atoms $\mathrm{Cl}^{-}$per gram sediment dry weight per week. The average number of chlorines per biphenyl decreased from 4.8 or 4.9 to 2.9 or 3.0 following 250 to 260 days of incubation of samples from the Twelve Mile Creek arm of the lake. The paper did not state the original concentrations of PCBs, but V. Magar (Environ Corp., pers. com. 2005) indicated that concentrations of PCBs in lake sediments range from trace levels to $60 \mathrm{mg} / \mathrm{kg}$ (Brenner et al. 2004). Based on sediment cores, Magar et al. (2005b) estimated dechlorination rates of PCBs in Lake Hartwell sediments at $0.094 \pm 0.063 \mathrm{~mol}$ of $\mathrm{Cl} / \mathrm{mol}$ of $\mathrm{PCB} / \mathrm{yr}$, indicating that $16.4 \pm 11.6 \mathrm{yr}$ was required for each (meta plus para) $\mathrm{Cl}$ removal. Magar et al. (2005a) indicated that the extent of dechlorination did not appear to correlate with PCB concentration, total organic carbon, or age of contamination.

Fate of PCBs in Sediments of the P1 Pond. A primary mechanism of reduction of PCBs in the P1 Pond under current conditions is probably the deposition of cleaner sediments, but with the absence of vegetation root structure, the presence of high suspended solids, and extensive sediment bioturbation by fish, sediment settling may be of short duration. The current pond probably supports limited dechlorination and biodegradation processes, although rates have not been measured, and the extent to which these processes are occurring is uncertain. Dechlorination would likely be very slow because: (1) bioturbation by common carp and other biota may be oxygenating the sediments and decreasing reductive dechlorination, (2) the concentration of PCBs in pond sediments is lower than the threshold for dechlorination in some sediments, and (3) high concentrations of polycyclic aromatic hydrocarbons may be associated with a nonaqueous phase that decreases the bioavailability of PCBs to PCB-degrading microorganisms in the pond. 
The proposed Ecological Management alternative may enhance dechlorination and biodegradation processes, or at the very least should not increase PCB concentrations in sediments or reduce their degradation. The stabilization of sediments by adding macrophytes and removing common carp should allow the deposition of cleaner sediments that remain relatively undisturbed. Anoxic conditions should prevail in sediments that are below the photic zone and not routinely disturbed (and oxygenated) by fish, although there is some uncertainty about how sediment oxygenation might change as a result of vegetation in the pond. Rooted emergent and submersed aquatic vegetation will tend to increase sediment oxygen levels, but terrestrial vegetation has been shown to increase rates of PCB dechlorination, and aquatic macrophytes might perform the same service in a pond (see below). PCBs will sorb to macrophytes, but probably with no greater a partition coefficient than to algae.

Fate of PCBs in Plants. Some pollutants that occur within sediments, such as PCBs, can become incorporated into leaves and stems of submersed aquatic plants (Stewart et al. 1992; Hopple and Foster 1996; Lovett-Doust et al. 1997; Vanier et al. 1999). Emergent aquatic plants that grow in sediments containing elevated levels of mercury can incorporate mercury into their tissues and lacunar systems, and export the metal, in gaseous phase, to the atmosphere (cf. Poissant et al. 2003). A literature search using Web of Science did not yield any published information on the rates at which emergent macrophytes might "pump" PCBs from PCBs-enriched sediments into the air. There has also been some research on PCB phytoremediation, where soils or sediments are remediated through harvesting of plants with an affinity for bioaccumulation. However, the technical basis for accomplishing this has not yet been well established. The results of studies relevant to this possibility have been published in the peer-reviewed literature by Mehmannavaz et al. (2002), Campanella et al. (2002), Ryslava et al. (2003), Sung et al. (2003) and Chekol et al. (2004).

Some aquatic plants clearly produce enzymes that can break down recalcitrant organic compounds such as trinitrotoluene (TNT) and RDX (cf. Best et al. 1999). Furthermore, some types of terrestrial plants (and perhaps some types of emergent aquatic plants) can produce compounds that can encourage the development of soil or sediment microbes capable of degrading PCBs. Evidence is accumulating to suggest that PCB concentrations are reduced slowly (presumably by specialized bacteria) in soil around the roots of terrestrial plants. This has not been demonstrated yet for rooted aquatic plants. However, rooted aquatic plants certainly will not increase the concentration of PCBs in sediment, so rooted emergent and floating-leaved aquatic plants might either not affect PCBs in the pond's sediment, or hasten their gradual loss.

\section{PCB BIOACCUMULATION MODEL}

A PCB bioaccumulation model was developed in an effort to evaluate how various remedial actions and changes to PCB processes might affect PCB accumulation in fish. The model is described and the various assumptions used in the model are presented in the first subsection, Model Assumptions. The results of various model runs (e.g., PCB bioaccumulation in fish with or without storm drain inputs) is reported and discussed in the second subsection (Results of Model Runs).

\section{Model Assumptions}

The transport and accumulation of PCBs in the pond were modeled using a steady-state model in which aqueous PCB concentrations were determined by setting the rates of PCB inputs equal to the rates of removal after PCBs had been distributed among dissolved, particle-associated, and organic carbonassociated phases. Total PCBs were modeled as a single compound rather than a mixture of various congeners. 
PCBs were assumed to enter the pond water via the storm drain system, from resuspension of contaminated sediments, and from diffusion across the sediment:water interface. Once in the water, PCBs could be lost via outflow, volatilization, and sedimentation after adsorption by suspended particles. For a special case in which rooted aquatic vegetation (macrophytes) replaced phytoplankton as the dominant plant life in the pond, the model was modified to reflect the fact that PCBs sorbed to these plants were not exported via the pond spillway, but were deposited to the sediments as the plants gradually senesced. The average total PCB concentration in bulk sediments $(0-15 \mathrm{~cm}$ depth) was assumed to be $2.7 \mathrm{mg} / \mathrm{kg}$ dry weight. Since sediments re-suspended by fish would be biased towards lighter, smaller particles which have a higher affinity for PCBs, the material subject to active re-suspension was assumed to have a PCB concentration of $4.0 \mathrm{mg} / \mathrm{kg}$.

PCB Partitioning Assumptions. PCBs were assumed to partition between dissolved, particleassociated, and dissolved organic carbon-associated phases according to linear distribution coefficients:

$$
\begin{aligned}
& {[\mathrm{PCB}]_{\text {diss }}=[\mathrm{PCB}]_{\text {sed }} / \mathrm{K}_{\mathrm{d}}} \\
& {[\mathrm{PCB}]_{\text {diss }}=[\mathrm{PCB}]_{\mathrm{oc}} /\left(0.1^{*} \mathrm{~K}_{\mathrm{ow}}\right)} \\
& {[\mathrm{PCB}]_{\text {diss }}=[\mathrm{PCB}]_{\mathrm{tss}} / \mathrm{K}_{\mathrm{d}}} \\
& {[\mathrm{PCB}]_{\text {total }}=[\mathrm{PCB}]_{\text {diss }}+[\mathrm{PCB}]_{\mathrm{oc}}+[\mathrm{PCB}]_{\text {tss }}}
\end{aligned}
$$

where:

$[\mathrm{PCB}]_{\text {diss }}$ is the concentration of dissolved PCB $(\mathrm{ng} / \mathrm{L})$

$[\mathrm{PCB}]_{\text {sed }}$ is the concentration of PCB on dry sediment $(\mathrm{ng} / \mathrm{kg})$

$[\mathrm{PCB}]_{\mathrm{oc}}$ is the concentration of $\mathrm{PCB}$ associated with dissolved organic carbon

$[\mathrm{PCB}]_{\mathrm{tss}}$ is the concentration of PCB on dry suspended solids

$\mathrm{K}_{\mathrm{d}}$ is the sediment:water partition coefficient $(\mathrm{L} / \mathrm{kg})$

$\mathrm{K}_{\mathrm{ow}}$ is the octanol water partition coefficient for PCB (dimensionless)

\section{PCB inputs (ng/day) were calculated as follows:}

$\mathrm{PCB}$ input from storm drain source $=[\mathrm{PCB}]_{\mathrm{SD}} * \mathrm{~F}_{\mathrm{SD}}$

PCB diffusive input from sediments $=10 * \mathrm{D}^{*}\left([\mathrm{PCB}]_{\mathrm{sed}} / \mathrm{K}_{\mathrm{d}}\right) * \mathrm{~A}$

$\mathrm{PCB}$ input from sediment re-suspension $=\mathrm{R} *[\mathrm{PCB}]_{\text {sed }} * \mathrm{~A} / 1000$

where:

$[\mathrm{PCB}]_{\mathrm{SD}}$ is the total concentration of PCBs in storm drain water $(\mathrm{ng} / \mathrm{L})$

$\mathrm{F}_{\mathrm{SD}}$ is the mean flow of the storm drain (L/day)

$\mathrm{D}$ is the diffusive mass transfer coefficient for transfer from the sediment interface to the water column $(\mathrm{cm} / \mathrm{h})$ 
A is the area of the pond $\left(\mathrm{m}^{2}\right)$

$\mathrm{R}$ is the sediment re-suspension rate $\left(\mathrm{g} / \mathrm{m}^{2} /\right.$ day $)$

\title{
PCB losses (ng/day) from the pond water column were calculated as:
}

\author{
PCB loss from outflow $=[\mathrm{PCB}]_{\text {total }} * \mathrm{~F}_{\text {out }}$ \\ PCB loss from volatilization $=24 * 10 * \mathrm{~V} *[\mathrm{PCB}]_{\mathrm{diss}} * \mathrm{~A}$ \\ PCB loss from particle settling $=10 * \mathrm{~S} * \mathrm{TSS} *[\mathrm{PCB}]_{\mathrm{tss}} * \mathrm{~A}$
}

where:

$\mathrm{F}_{\text {out }}$ is the flow out of the pond (L/day)

$\mathrm{V}$ is the mass transfer coefficient for volatilization of PCBs across the water surface $(\mathrm{cm} / \mathrm{h})$

TSS is the concentration of suspended solids in the water column $(\mathrm{mg} / \mathrm{L})$

$\mathrm{S}$ is the settling velocity of suspended solids ( $\mathrm{cm} /$ day)

PCB Bioaccumulation Estimates. The accumulation of PCBs by fish was estimated by coupling the modeled $[\mathrm{PCB}]_{\text {diss }}$ with the baseline PCB bioaccumulation factor (BAF) proposed in EPA 1996.

$$
\mathrm{BAF}=26,735,000
$$

where $\mathrm{BAF}$ is the dimensionless ratio of $\mathrm{PCB}$ concentration in fish lipids to $[\mathrm{PCB}]_{\text {diss }}$ for a Trophic level 3 fish (forage fish). The concentration of PCBs in a forage fish (wet weight basis) would thus be:

$$
[\mathrm{PCB}]_{\mathrm{fish}}=[\mathrm{PCB}]_{\mathrm{diss}} * \text { lipid fraction of fish } * \mathrm{BAF}
$$

This approach was used to estimate the PCB concentration in gizzard shad and bluegill in P1 Pond in the model. Empirical data demonstrating that PCB concentrations in large bass in P1 were similar to those in shad were used to set the concentration of PCBs in bass equal to that of its prey (bluegill or shad). Empirical data from monitoring PCBs in P1 bass were also used to establish the relationship between BAF (wet wt basis, not lipid basis) and fish size (Fig. 5). Larger bass were found to have higher lipid content than smaller bass, and lipid-based BAF also increased with size, probably reflecting the higher PCB content of the food of larger fish.

Estimates of PCBs in Water. The model was constructed using empirically measured or literature derived parameters (Table 1). The initial total aqueous PCB concentration was estimated using results of caged clams (Carbicula fluminea) held for four weeks in the outfall of P1 Pond. It was assumed that clams accumulated PCBs from all aqueous phases (particulate, dissolved and colloidal) and attained a degree of bioconcentration represented by a BAF (wet weight, soft tissue) of 32,000. Preliminary results of laboratory measurements of clam filtration rates indicate that uptake rates of $25-50 \mathrm{~h}^{-1}$ (filtration rate of $25-50 \mathrm{ml} / \mathrm{g} / \mathrm{h}$ ) are reasonable, corresponding to 30 -day BAFs of 18,000 to 36,000 . PCB concentration in 


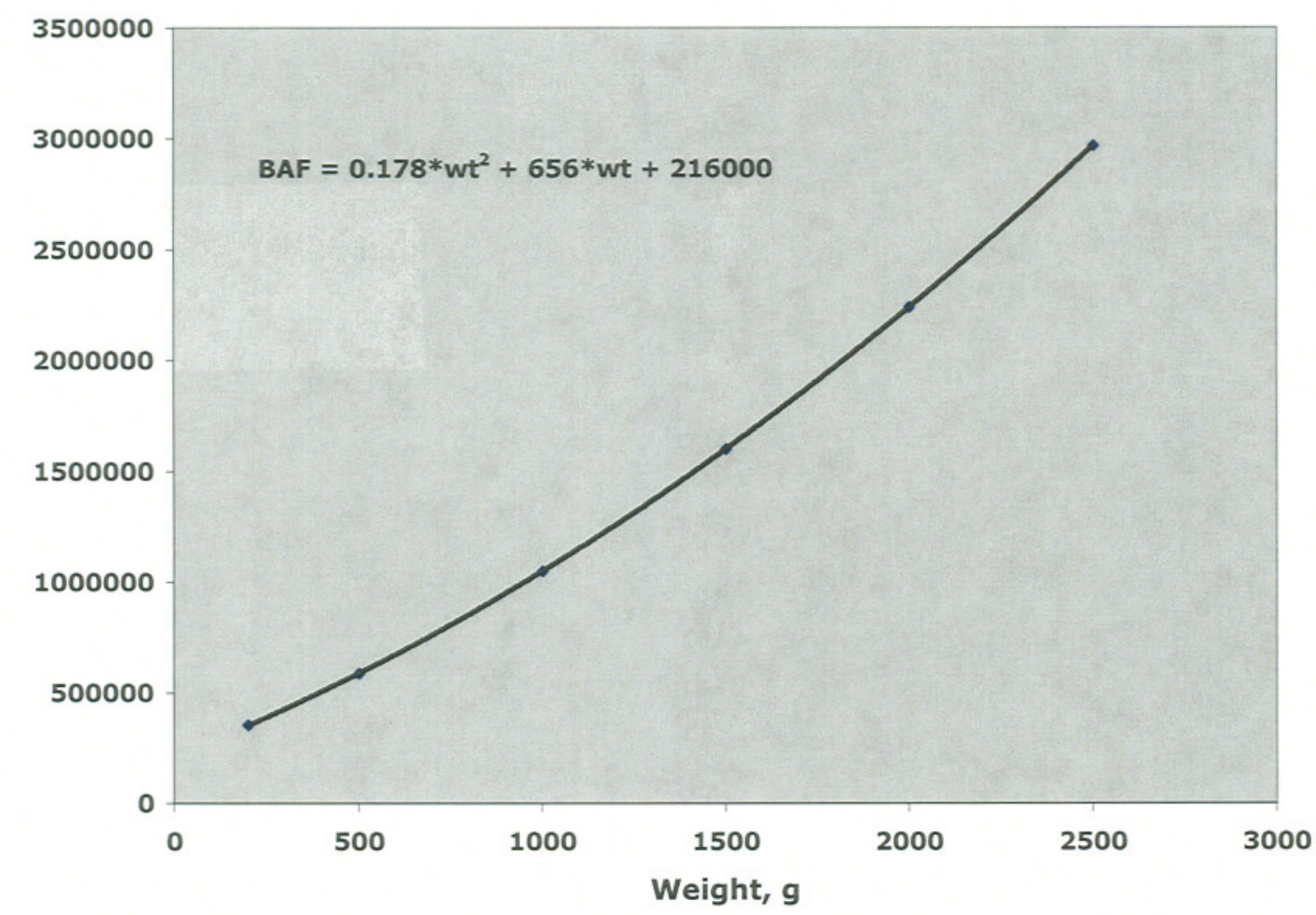

Fig. 5. Variation in estimated BAF (bioaccumulation factor, wet weight basis) of largemouth bass in P1 Pond with fish weight. The observed variation in lipid content and concentration of PCBs in lipids was used to construct the relationship, with an assumed BAF of 1,600,000 for a 1500-gram fish.

the storm drain input was calculated in the same way, using data from clams deployed in water at the outlet of SD 100. Parameters in the baseline model were then adjusted to meet two constraints based on monitoring data: (1) the concentration of PCBs in shad should approximate that observed in P1 Pond, and (2) the total PCB concentration in the pond outflow should be approximately $25 \%$ of that in the storm drain input.

PCB concentrations in caged clams were used to infer, not measure, total waterborne PCB concentrations, and are subject to uncertainties associated with any assumptions used in making such an inference. Because the magnitude of storm drain sources of PCBs to the P1 system are a critical factor in determining what actions are needed at this site, direct measurement of PCBs in the P1 outfall and storm drain inputs were made by BJC in spring 2005 using flow-proportional sampling to enable direct calculation of PCB fluxes (R. Kettelle, pers. comm. 2005). Results of the direct measurement of PCBs in water differed greatly from concentrations estimated from clam bioaccumulation. PCBs were not detected in storm drain inputs to the pond (detection limit 14-49 $\mathrm{ng} / \mathrm{L}$ ) and were only detected on one occasion at the pond outfall (19 $\mathrm{ng} / \mathrm{L}$ in a sample containing $21 \mathrm{mg} / \mathrm{kg}$ TSS). 
Table 1. Values of input variables used in the steady-state PCB bioaccumulation model. Because of the large difference between measured and inferred concentrations of PCBs in storm drain inputs to P1 Pond, most hypothetical actions at the P1 Pond were evaluated using two different assumed average PCB concentrations $-232 \mathrm{ng} / \mathrm{L}$ (based on clam data), and $12 \mathrm{ng} / \mathrm{L}$ (based on detection limits of the direct PCB measurements).

\begin{tabular}{lccl}
\hline \multicolumn{1}{c}{ Input Variables } & Value & Units & \multicolumn{1}{c}{ Reference } \\
\hline Sediment:water distribution coefficient & & & \\
Total suspended solids (TSS) & 75,000 & $\mathrm{~L} / \mathrm{kg}$ & Thomann and Mueller 1983 \\
PCB octanol:water partition coefficient & 20 & $\mathrm{mg} / \mathrm{L}$ & Peterson et al. 2005 \\
Dissolved organic carbon & $3,000,000$ & dimensionless & Mackay et al. 1983 \\
Sediment resuspension rate & 8 & $\mathrm{mg} / \mathrm{L}$ & A.J. Stewart, pers. comm. 2005 \\
Storm drain PCB concentration & 1.5 & $\mathrm{~g} / \mathrm{m}^{2} / \mathrm{d}$ & Mundhall 1991 \\
Sediment settling velocity & 250 & $\mathrm{ng} / \mathrm{L}$ & calculated \\
PCB concentration on sediments & 20 & $\mathrm{~cm} / \mathrm{d}$ & Richardson et al. 1983 \\
Volatilization coefficient & 4 & $\mathrm{mg} / \mathrm{kg}$ & Day, pers. comm., 2005 \\
Desorption coefficient (from bedded sediment) & 0.3 & $\mathrm{~cm} / \mathrm{h}$ & Thomann and Mueller 1983 \\
Mean depth & 0.1 & $\mathrm{~cm} / \mathrm{h}$ & Southworth 1979 \\
Pond area & 1.5 & $\mathrm{~m}$ & Peterson et al. 2005 \\
Water level (relative to full pool) & 93,400 & $\mathrm{~m}{ }^{2}$ & Peterson et al. 2005 \\
Storm drain flow & 0 & $-\mathrm{m}$ & \\
Outfall flow & 38,000 & $\mathrm{~L} / \mathrm{d}$ & Peterson et al. 2005 \\
Fish biomass & $4,300,000$ & $\mathrm{~L} / \mathrm{d}$ & Peterson et al. 2005 \\
Macrophyte density & 1350 & $\mathrm{~kg} / \mathrm{ha}$ & Peterson et al. 2005 \\
Macrophyte senescence rate & 150 & $\mathrm{~g} / \mathrm{m}^{2}$ & A.J. Stewart, pers. comm. 2005 \\
BAF (bioaccumulation factor) & 0.015 & fraction/d & A.J. Stewart, pers. comm. 2005 \\
$\quad$ gizzard shad (whole body) & $\mathrm{L} / \mathrm{kg}$ & \\
$\quad$ bluegill (whole body) & $1,600,000$ & & EPA 1996 \\
$\quad$ large bass (fillet) & 540,000 & & EPA 1996 \\
$\quad$ small bass (fillet) & equals BAF of prey & & estimated from site-specific data \\
\hline
\end{tabular}


Estimates of total waterborne PCBs from clam bioaccumulation were $232 \mathrm{ng} / \mathrm{L}$ for storm drain inputs and $58 \mathrm{ng} / \mathrm{L}$ for the pond discharge. Each approach (clam biomonitoring versus direct measurement) is subject to possible biases and sources of error. Historical data for clam bioaccumulation at SD 100 could have been influenced by re-suspension of sediments in the pond at the discharge point, since the discharge was in the pond itself. However, monitoring conducted in 2005 within SD 100 upstream from pond influence also found clams to accumulate PCBs (approximately $40 \%$ of the concentration attained in clams at the downstream point). Clams held within SD 100 suffered high mortality during the exposure period, suggesting that they could have accumulated higher concentrations had they remained healthy. The application of a higher bioaccumulation factor for inferring aqueous concentrations from clams would have yielded lower estimates, but would have been proportionately the same for storm drain inputs and pond discharge, and hence made little difference in determining the contribution of storm drain inputs to PCB concentration at the pond outlet. Direct measurement of PCBs in water at part per trillion concentrations is also fraught with difficulty and subject to possible bias. PCBs, particularly in clear water low in TSS and dissolved organic carbon, are highly surface reactive and lipophilic: they tend to adsorb to surfaces, particularly plastics such as teflon tubing or the soft plastic tubing commonly used in peristaltic pumps. PCBs also are volatile from water, and losses to the container headspace could occur in the collection of composite samples over a period of time (as would be done in either time-proportional or flow proportional sampling).

\section{Results of Model Runs}

Model results are summarized in Table 2 and scenario-specific outputs are presented in Appendix B.

Baseline. The results for the baseline ([PCB] $=57 \mathrm{ng} / \mathrm{L}$ in outfall, $232 \mathrm{ng} / \mathrm{L}$ in storm drain) condition in P1 Pond are shown in Table 2 and Appendix B. PCB concentrations in largemouth bass and their prey (gizzard shad) are very high at $19 \mathrm{mg} / \mathrm{kg}(\mathrm{ppm})$. Much of the total waterborne PCB concentration is associated with suspended particles, which contain $0.9 \mathrm{mg} / \mathrm{kg}$ PCBs. The major source of PCBs to water (and fish) in this scenario is the internal recycling of PCBs from sediments to water as a consequence of bioturbation by large bottom feeding fish (carp, buffalo, catfish) and gizzard shad, which actually mouth and ingest sediments to extract food. Thus, PCBs associated with sediment are redistributed in the water column, where a fraction of the PCBs dissolve those particulates and redistribute among dissolved, particulate, and colloidal phases. The pond is a net source of PCBs under this scenario, with losses (volatilization, $79 \mathrm{mg} / \mathrm{d}$ and outflow, $247 \mathrm{mg} / \mathrm{d}$,) exceeding inputs (storm drain flux, $88 \mathrm{mg} / \mathrm{d}$ ) by $238 \mathrm{mg} / \mathrm{d}$. The inventory of PCBs estimated to reside in pond sediments is $37.8 \mathrm{~kg}$ (assuming a uniform depth of $15 \mathrm{~cm}$ and average concentration of $2.7 \mathrm{mg} / \mathrm{kg}$ ). Under this scenario, annual net loss of PCBs from the pond is quite small relative to the inventory in pond sediments yielding a calculated turnover time of 318 years. The inventory of PCBs stored in fish, $158 \mathrm{~g}$ is likewise a small fraction of the sediment inventory.

Elimination/Absence of Storm Drain Inputs. This run represents the case in which storm drain inputs of PCBs were eliminated or were insignificant to start with. All other input parameters remained unchanged. Results are depicted in Table 2 and Appendix B. In this scenario, total PCB concentration at the pond discharge is reduced from 57 to $50 \mathrm{ng} / \mathrm{L}$, and PCB concentrations in fish from 19 to $16 \mathrm{mg} / \mathrm{kg}$. At $12 \mathrm{ng} / \mathrm{L},<1 \%$ of the PCB inputs come from the storm drain system.

Elimination of Bioturbation and Gizzard Shad. This scenario embodies the key elements of the Ecological Management option for P1 Pond. Sediment resuspension rate is set at zero, a consequence of eliminating bioturbation and allowing rooted vegetation to stabilize sediments. The pond is still modeled as a planktonic system, but secondary production (conversion of primary production to animal biomass) is 
Table 2. Output of steady-state PCB transport model under various treatment actions at P1 Pond.

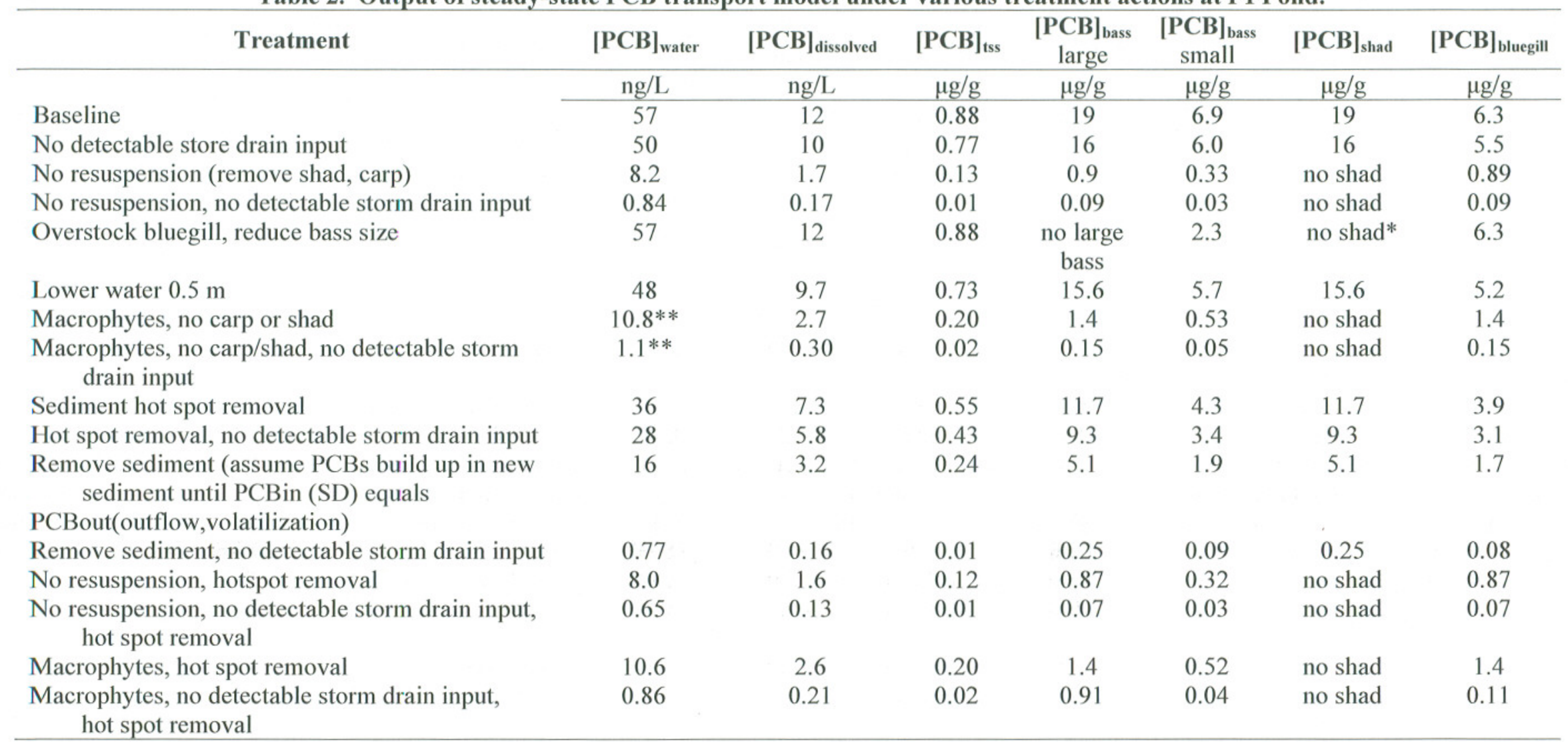

*Assume small shad abundance too low to be prey of small bass.

**Excludes PCBs on macrophytes. 
assumed to be confined to the water column. (A later run will specifically deal with the conversion of the pond to a system fully covered by rooted aquatic plants.) This run therefore represents a 'best case' in which the benthic food chain is eliminated. Results are depicted in Table 2 and Appendix B. PCB concentration in fillets of large bass are predicted to decrease from $19 \mathrm{mg} / \mathrm{kg}$ in the baseline case to $0.9 \mathrm{mg} / \mathrm{kg}$ in this scenario. If ecological conditions are altered to disfavor the efficient growth of large bass, reducing the mean size of bass in P1 Pond to 500 grams (from 1500 grams), the average concentration in bass would be further reduced to $0.3 \mathrm{mg} / \mathrm{kg}$.

No Bioturbation in the Absence of Storm Drain Inputs. If the PCB concentration in storm drain inputs is set at $12 \mathrm{ng} / \mathrm{L}$ rather than $232 \mathrm{ng} / \mathrm{L}$ as in the preceding case, the predicted concentrations in bass drop by another factor of 10 (Table 2, Appendix B), reflecting the near absence of PCB sources in the model under these conditions.

Reduction in Water Level. One option under consideration for facilitating the establishment and growth of rooted aquatic vegetation in P1 Pond is lowering the water level to increase sunlight intensity near the bottom of the pond. P1 Pond appears to be approximately $0.5 \mathrm{~m}$ higher in elevation than Poplar Creek under summertime full pool conditions in Watts Bar Reservoir, therefore a $0.5 \mathrm{~m}$ drop in water level was evaluated. Results of this action alone on PCB bioaccumulation were beneficial but relatively minor (Table 2, Appendix B). PCBs in large bass were predicted to decrease to approximately $16 \mathrm{mg} / \mathrm{kg}$, while waterborne total PCB declined from 57 to $48 \mathrm{ng} / \mathrm{L}$.

Alteration of Fish Community Size Structure. The present conditions in P1 Pond are highly desirable from a fisheries management point of view, with the production of large numbers of large, even trophy size, bass. One action likely to be taken in concert with the habitat enhancements would be to favor the establishment of sub-optimum conditions for the production of large predator fish - essentially, creating a system in which desired prey fish abundance is very high, resulting in a stunted population which exerts strong competitive pressure on early life history stages of other prey species (such as gizzard shad). The modeled scenario is thus one in which bluegill populations become excessive, and small shad become numerically uncommon. Shad would exhibit rapid growth rates once they reach a size where competition with bluegill was relaxed, developing a population of fish too large to be prey for small $(500 \mathrm{~g})$ bass. Bass numbers would be increased by habitat alteration or introductions to create an overabundance similar to that of bluegill, resulting in a population structure with a relatively low average size, feeding upon bluegill. Results of this scenario suggest that, even if bioturbation was left unchanged, PCB concentrations in bass in the pond (Table 2) would average only $2.3 \mathrm{mg} / \mathrm{kg}$ (versus $18 \mathrm{mg} / \mathrm{kg}$ under the baseline case). Other species remaining in the pond (gizzard shad, carp, etc.) would continue to acquire high concentrations of PCBs; therefore this action would not represent a stand-alone solution to the problem, but would enhance the effectiveness of other actions at reducing risk to human consumers of fish.

Elimination of Bioturbation, Establishment of Macrophyte Community. The hypothetical ecological alteration of P1 Pond by the elimination of bioturbating fish would ideally be accompanied by the establishment of a pond-wide community of rooted aquatic vegetation that would stabilize the sediments with a dense mat of roots and tubers and fill the overlying water column with stems and leaves, providing cover and habitat for fish and invertebrate food organisms. Secondary production of invertebrates in the contaminated sediment would be greatly reduced by eliminating the steady inputs of settling plankton. The model was adjusted to incorporate a situation in which the pond becomes colonized by such plants. Predicted PCB concentrations in water and fish are very similar in this run to the run which preserved a planktonic system in the absence of bioturbation (Table 2, Appendix B). The key factor is the stabilization of PCB contaminated sediments (the planktonic system without bioturbation is not likely to be a sustainable or manageable condition). Although the model does export PCBs accumulated by macrophytes in a senescence algorithm, a higher aqueous dissolved PCB concentration is required to establish steady state conditions in the macrophyte dominated model. 
Macrophyte Dominated System with Storm Drain PCB $=12 \mathrm{ng} / \mathrm{L}$. If the above system is simulated with the storm drain PCB concentration set at $12 \mathrm{ng} / \mathrm{L}$, very low PCB concentrations are predicted in water and fish (Table 2).

Sediment Removal. An alternative approach for reducing PCB bioaccumulation in P1 Pond is the straightforward action of removing contaminated sediments. Two sediment removal scenarios are considered here - the removal of localized 'hotspots' and the complete removal of all sediments down to 'clean' soil.

In the case of localized removal of the most contaminated sediments, it was assumed that all sediments containing $5 \mathrm{mg} / \mathrm{kg}$ or greater total PCBs would be removed, and that this constituted $20 \%$ of the sediments in the pond ( $20 \%$ of the values used to estimate an average PCB concentration for P1 sediments exceeded $5 \mathrm{mg} / \mathrm{kg})$. The average PCB content of the remaining sediment $(1.5 \mathrm{mg} / \mathrm{kg})$ was used to characterize the pond after this action, assuming that 'clean' spots are refilled by re-suspended sediments at the new pond average. Under this scenario, with carp and shad remaining in the pond, predicted PCB concentrations in water and large bass were $36 \mathrm{ng} / \mathrm{L}$ and $11.7 \mathrm{mg} / \mathrm{kg}$, respectively (Table 2, Appendix B). With storm drain PCBs at $2 \mathrm{ng} / \mathrm{L}$, the resultant predictions were $28 \mathrm{ng} / \mathrm{L}$ and $9.3 \mathrm{mg} / \mathrm{kg}$.

In the case of removal of all P1 sediments, initial conditions (sediment $\mathrm{PCBs}=0$ ) change over time as new PCBs enter the pond and accumulate in sediments. Therefore, the sediment PCB concentration term was adjusted in the model from its initial set point (zero) until the pond reached a steady state (PCB inputs from storm drain were equal to loss via volatilization and outflow). Results of this run indicated that the pond would re-equilibrate at a sediment concentration of $0.42 \mathrm{mg} / \mathrm{kg}$ (bulk sediment). At that state, waterborne PCB concentration and PCBs in bass would be $16 \mathrm{ng} / \mathrm{L}$ and $5.1 \mathrm{mg} / \mathrm{kg}$.

Although recontamination appears to be a concern, it would not be immediately obvious since a substantial period of time would be required to attain such levels. If the effective depth of sediment (the well-mixed layer being re-suspended) is assumed to be $1 \mathrm{~cm}$, the time required to achieve a concentration of $0.42 \mathrm{mg} / \mathrm{kg}$ would be nine years at the assumed storm drain input rate. This assumes all PCBs go to sediment; since some PCBs would be lost to outflow and volatilization, a longer period would actually be expected. If, however, the more appropriate estimate of storm drain PCB concentration is $12 \mathrm{ng} / \mathrm{L}$, sediment removal would be much more effective, yielding steady state concentrations of $0.77 \mathrm{ng} / \mathrm{L}$ in water and $0.25 \mathrm{mg} / \mathrm{kg}$ in bass.

\section{Combination of Sediment Hotspot Removal and Ecological Management (Control of} Resuspension, Shad Removal, and Macrophyte Establishment). The final four runs in Table 2 show the predicted results of combining Ecological Management actions with sediment hotspot removal. The additional benefit of incorporating hotspot removal with Ecological Management is heavily influenced by the assumptions made about storm drain PCB inputs. When storm drain inputs are negligible, hot spot removal has a proportional effect on predicted PCB concentrations in fish. However, when sediments are not the lone source of PCBs, the added benefit of removing sediment hotspots is far less. This is because the predicted role of sediment PCBs as a source to pond biota has been greatly reduced by eliminating sediment resuspension, making storm drain inputs (which are unaffected by hot spot removal) the major source of PCBs.

\section{Modeling Conclusions}

PCB contamination in fish in P1 Pond appears to be driven primarily by PCB contamination in pond sediments and the presence of ecological conditions that serve to efficiently recycle PCBs to the water column and maximize their accumulation in predators. Results of modeling steady state PCB 
partitioning and flux in the system under various remedial action scenarios indicated that actions which isolated or removed sediments would lead to large reductions in biotic contamination.

Storm drain systems that discharge into P1 Pond, especially SD 100, are also sources of PCBs; however, the magnitude of these inputs is uncertain. If direct measurements that suggest total PCB concentrrations in storm drain discharges are $\leq 12 \mathrm{ng} / \mathrm{L}$ are correct, these sources are relatively inconsequential. If biomonitoring data that yield inferred aqueous PCB concentrations of approximately $230 \mathrm{ng} / \mathrm{L}$ in storm drain flows provide a more accurate estimate, controlling PCB accumulation through actions against sediment contamination only may not achieve satisfactory results.

\section{EVALUATION OF POTENTIAL ACTIONS}

Detailed evaluation of the potential Ecological Management actions including fish management, vegetation management, wildlife management, water quality manipulation, and preventive actions is provided in the following subsections. Each proposed action below includes multiple alternatives based on literature reviews and knowledge of assessment strategies. A concise summary of all final recommendations for the Ecological Management alternative are provided in the following section of this report ("Recommended Actions").

\section{Fish Management}

The methodology, potential effectiveness and relative cost of various fish management actions were examined. These options include (1) no changes in resident fish community, (2) complete removal of all fish, (3) moderate changes in abundance of target fish species, and (4) major restructuring of the fish community.

Based on surveys conducted during August 2004, the current fish community in the pond has a limited diversity but maintains a high abundance of fish (Peterson et al. 2005). The pond has 16 species, with most being species associated with pools or other areas where water velocity is low. The fish community is dominated numerically by sunfish and shad (Peterson et al. 2005) but has a visible component of large sucker and non-native carp. The suckers and carps are primarily bottom feeders and, along with gizzard shad (Dorosoma cepedianum), contribute to the resuspension of sediments by their feeding activities. Further, the grass carp (Ctenopharyngodon idella) feeds on aquatic and emergent vegetation and helps maintain an open water system. This promotes algal growth and reinforces the foodchain bioaccumulation of PCBs, where shad eat algae and bass eat shad. Options 2 through 4 are all PCB interdiction methods designed to break or weaken the food chain, thereby reducing environmental and human health risks.

Option 1: No Change in Resident Fish Community. The no-change alternative would be to leave the fish community in the P1 Pond as it is currently structured. Without fish management, the fish community in the pond is not likely to change over the long-term. It is possible that grass carp could eventually die out, as in the P3-P5 ponds, but this is less likely in the P1 Pond, because the population is large and was likely augmented from stocking as well as migration from Poplar Creek. PCB associated risks would remain high as the dominant forage fish would be shad and the primary piscivore predator would be largemouth bass (Micropterus salmoides). Common carp and other bottom feeders would continue to resuspend sediments and contribute to the PCB phytoplankton food chain (Fig. 3).

Conducting various source-reduction actions (removing sediment, ending storm drain inputs, etc.) while keeping the existing fish population was examined in the PCB Bioaccumulation Section of this report. The current fish population maximizes PCB bioaccumulation, and continued high levels in fish are 
expected unless there is near total source removal. Even in the absence of major sources, PCB concentrations in older and top-of-the-food-chain fish would likely remain high for many years before decreasing to acceptable levels.

No fish management costs would be associated with this option.

Option 2: Complete Removal of All Fish. Complete removal and permanent burial of P1 fish describes this option. Taking all fish out of the pond would immediately reduce PCB risks associated with fish to ecological and human receptors. Permanent fish removal would entail lowering the water level, using rotenone treatment (which should kill all fish and their eggs), then burying the fish in a hole dug on shore. This option assumes that having no fish in the pond is the goal and no selective fish sampling, fish stocking, or vegetation management is part of this option.

This option would be similar to the K901A remediation, where the pond was drained, fish removed and buried locally, and contamination associated with sediments removed. In the case of K901A, fish quickly repopulated the pond from the Clinch River, and within two years contaminant concentrations in fish were similar to pre-remediation concentrations. If no fish in the P1 Pond is the goal, preventive actions are required to prevent fish from entering the pond. Increasing the height of Burchfield Road would ensure fish cannot enter the pond from Poplar Creek. Rotenone treatment would be needed in all upstream ponds and small streams to ensure small fish do not enter P1 from those areas. Preventing large fish that disturb sediments from entering the pond, using these preventive actions, is likely under this alternative. However, these actions would have a low probability of keeping all fish from entering the pond over the long term, because smaller fish species (minnows, sunfish) that are present in small pond tributaries would be extremely difficult to eliminate.. Follow-up rotenone treatments probably would be required to keep fish out of the pond forever.

A large pond without fish is not an end-state that appears to be sustainable without continued rotenone treatment. It is difficult to predict what fish community would predominate in the P1 Pond if the pond was left to equilibrate without continued rotenone treatments in future years, because the community would develop depending on the timing and nature of unknown fish immigration events, and on the pond's condition and suitability to some species at the time of the immigration events.

Costs for this alternative would be similar to the wholesale-change option, except cost would be slightly lower in the first two years as no present fish would be managed or manipulated. However, costs for this option are deemed higher over the long-term, with extensive monitoring and rotenone treatment costs likely needed in future years.

Option 3: Moderate Changes in Abundance of Target Species. The moderate-change alternative would focus on removal of select target species in order to modify the fish community. The target species would include large suckers and carps, shad, and all specimens of bass. The selective removal would be achieved by lowering the pond water level, then using a combination of size-selective gill nets and repeated electrofishing for the target fish. Fish removed from the pond would be buried on shore.

Methods proposed here are likely to make major changes in the fish community in the pond in the short-term, but are not expected to completely eliminate undesirable species (gill netting and electrofishing are not $100 \%$ effective). No rotenone treatment is required and upstream preventive actions are unnecessary, as there is an assumption a few undesirable species will be left in the P1 Pond.

The effectiveness of this option is highly dependent on making a substantial reduction in the numbers of undesirable fish. Of particular importance would be the complete removal of grass carp, given 
its importance in defining the environmental conditions in the pond. Preventing the pond from reverting to its previous condition is dependent on quickly establishing vegetation in the pond, which would require total or near-total removal of this species. Making significant reductions in the common carp, large suckers, and largemouth bass populations in the pond is also possible, and will result in near immediate reductions in human health risks associated with fish in the pond. Reduction of ecological risks associated with this option, however, even in the short-term, is more uncertain. Gizzard shad are extremely abundant in the pond. Even if only a few fish remain after selective sampling, shad are prolific and will quickly repopulate if open-water conditions and nutrient enrichment persist. This option should be considered only in concert with other actions, such as vegetation enhancement and water-quality control, which would reduce the likelihood that the fish community would revert to the current conditions.

The moderate-change option is the least costly of the active fish management actions, but it is also the most uncertain as to effectiveness in the long-term.

Option 4: Major Restructuring of the Fish Community. This option involves a major restructuring of the fish community to completely remove undesirable fish while enhancing the assemblage of fish that contain very low PCBs (namely sunfish and small minnows). This is the recommended option as it is the most likely approach to produce a successful, long-term fish community end-state, and has a high probability of influencing PCB exposure of the environment and humans.

This option would entail temporary removal of desirable fish species [sunfish species, small minnow species, and miscellaneous species that occur at low densities (e.g., western mosquitofish, Gambusia affinis)], removal and burial of undesirable species using rotenone, and then a return of the desirable species to the pond. Method details are provided in the Recommended Actions Section. Without any other actions to minimize PCB bioaccumulation, this fish management action alone would immediately reduce ecological and human health risks associated with pond fish, as the remaining sunfish and minnows presently in the pond are of low risk to human and ecological receptors (Peterson et al. 2005). Unlike the total-removal option, the community of sunfish and small minnows is sustainable, and the pond in such condition would be a desirable natural resource (particularly if vegetated; see Natural Resource section). Preventive actions, including restructuring of the P3-P5 fish communities, and enhancing the road barrier between P1 Pond and Poplar Creek, are recommended as part of this action. Once restructured upstream (namely, removing bass), movement of fish from upstream areas is not detrimental to the goals of this option and long-term fish community management in the P1 Pond is unlikely.

The remaining fish would be primarily invertebrate feeders with some piscivory possible from large individuals (Fig. 4). The resulting food chain would deemphasize the bioaccumulation steps that are currently occurring through shad forage and large piscivores. Conditions would likely encourage dense sunfish populations with few large individuals. If needed, small sunfish could be stocked to speed up the process and further skew the community to a stunted sunfish design. Once established with extensive vegetation, these small-sunfish dominated ponds are extremely difficult to change to another community type.

This option has the highest short-term costs of the three active fish management options, but has lower long-term costs. Details of this recommended action are provided in the following section.

\section{Vegetation Management}

The reestablishment of aquatic vegetation in the P1 Pond is an important component of the Ecological Management action. Actions to ensure that aquatic plants thrive in the pond include removing grass carp and temporarily modifying water quality to increase light penetration. With sediment- 
perturbating fish absent and clear water present, P1 conditions should be ideal for establishing a dense cover of aquatic plants. Aquatic plants will provide a number of benefits that will help reduce PCB bioaccumulation in the pond. In this section, a general overview of vegetation management and its potential role in the Ecological Management alternative is provided, along with a discussion of the potential planting methods and species selection.

Overview of the Role of Aquatic Plants in Affecting P1 Pond Ecological Processes.

Establishing dense beds of macrophytes in the pond is an important step in the proposed ecological manipulation, because the presence of aquatic plants promotes the following conditions:

- greater water clarity;

- more stable sediments;

- increased heterogeneity of habitat for aquatic invertebrates, amphibians and fish;

- alternative forage for waterbirds;

- reduced foraging success by birds such as herons and kingfishers; and

- greater diversity of aquatic insects.

The trophodynamic structure of aquatic systems that are dominated by rooted submersed and emergent macrophytes differs fundamentally from those dominated by plankonic primary producers. Key differences between shallow-water freshwater systems dominated by these two types of primary producers are summarized in Table 3. When beds of aquatic macrophytes are well established, they can reduce phytoplankton abundance by competing for phosphorus, reducing turbulence, and by reducing the available light (Wetzel 2001). These conditions are less conducive for phytoplankton. As a result, more macrophytes mean less open water and less food available to support gizzard shad. Thus, macrophytes are an important means for "short circuiting" the trophic transfer of PCBs from sediment and algae, through shad, to bass.

The single most important factor in affecting the success of aquatic plants is water clarity. As a general rule, submersed aquatic plants can grow to depths where the light intensity is as low as $1 \%$ to $4 \%$ of the average intensity at the surface of the water (Sculthorpe 1985). In systems that have relatively clear water, this depth can be as great as $\sim 10 \mathrm{~m}$. Furthermore, some types of rooted emergent macrophytes can live at depths of up to $1.5 \mathrm{~m}$, and some floating-leaved macrophytes can live in water as deep as $3 \mathrm{~m}$ (Wetzel 2001), if the water is clear. The depth to which light readily penetrates can be approximated by a Secchi disk. Presently, in the P1 Pond, the Secchi disk depth is only about 40 to $60 \mathrm{~cm}$ (Peterson et al. 2005 , Table 11). Thus, only about $10 \%$ to $20 \%$ of the pond's present surface area might be suitable habitat for submersed aquatic plants at this time, due to turbidity. If water clarity could be controlled sufficiently (by removing carp and algaecide treatment initially), virtually the entire area of the P1 Pond could become suitable for the growth of submersed, floating-leaved or emergent aquatic macrophytes. Phytoplankton control should not be needed when the macrophytes have become well established, because macrophyte-dominated ponds tend to be ecologically stable.

A "weed choked" pond system provides spatial refugia for fish and reduces the foraging effectiveness of shallow-water wading birds such as herons. This condition should reduce further the flux of PCBs to avian receptors. Aquatic plants also provide habitat and forage base (in the form of epiphytes) for a diverse array of aquatic macroinvertebrates, including odonates (dragonflies and damselflies). The expectation is that with a greater diversity and abundance of aquatic plants, there will be more kinds of emergent aquatic insects, which will extend the range of insects available to consumers such as adult frogs, swallows and bats. Thick stands of emergent aquatic plants around the pond's shoreline also reduce access of the pond to Canada geese, which should lower the rate of phosphorus loading (Manny et al. 1975). 
Table 3. Trophodynamic properties of pond ecosystems in which primary production is dominated by planktonic algae versus submersed and emergent rooted aquatic macrophytes.

\begin{tabular}{cl}
\hline $\begin{array}{c}\text { Dominant Primary } \\
\text { Producers }\end{array}$ & \multicolumn{1}{c}{$\begin{array}{c}\text { Trophic Pathways } \\
\text { and Considerations }\end{array}$} \\
\hline Planktonic algae & $\begin{array}{l}\text { Colonial or single-celled planktonic } \\
\text { algae in open-water habitats } \rightarrow \text { filter- } \\
\text { feeding fish (e.g., shad) } \rightarrow \text { large- } \\
\text { bodied predatory fish (e.g., bass). }\end{array}$ \\
& However, the dominant detrital \\
pathway is planktonic carbon $\rightarrow$ \\
sediment, by sedimentation. Organic \\
carbon deposited to the sediments is \\
processed primarily by microbes and \\
detritivores: detrital carbon dynamics \\
are constrained and shaped by the \\
availability of oxygen or alternative \\
electron acceptors (Rich and Wetzel \\
1978), and the flux of organic carbon \\
to sediments encourages the \\
development of populations of fish, \\
such as carp, that feed on organisms \\
exploiting the organic carbon-rich \\
sediments.
\end{tabular}

Submersed and emergent rooted macrophytes
Relative to algae, these plants contain more structural carbon, resulting in slower-cycling, relatively recalcitrant organic detrital carbon. Also, periphyton and metaphyton communities $\rightarrow$ primary consumers that prefer surfaces $\rightarrow$ visual-feeding predatory fish and invertebrates.
Key Mechanisms and Environmental Properties Larger-bodied efficient primary consumers (such as shad) can dominate in expansive planktonic (open-water) habitats. Turbid conditions due to excessive planktonic algae and sediments frequently disturbed by carp reduce light penetration. The reduced light penetration in turn increases the tendency for shallow thermal stratification. The flux of organic carbon to the sediments also encourages the trend toward strong diel cycles in dissolved oxygen in photic zone. The system's heat-storage capabilities are reduced, compared to a clearer-water system, because light penetrates less deeply into the water.

Spatially complex habitats created by macrophytes provide surface area for attached microproducers and refugia for invertebrates and young-of-year sightfeeding fish (bluegill, bass); interception and attenuation of light by larger-bodied plants or attached algae reduces the success of planktonic algae. Energy is diverted from detrital microbial pathways to larger-bodied, sight-feeding consumers. Deeper penetration of light in the clearer-water open areas increases the system's heatstorage capacity. 
Key information about the physiology, morphology, distribution, ecology and taxonomic relations among water plants can be found in books by Hutchinson (1975), Sculthorpe (1985), and Fassett (1957). Wetzel (2001) and Dykyjová and Květ (1978) also provide excellent reviews of some aspects of aquatic plant community processes, as well.

Plant Species Selection - General Considerations. Numerous web sites contain good, credible information on selection and planting for a wide range of aquatic plants. Among these are the following:

http://plants.usda.gov/cgi_bin/topics.cgi

http://www.cropsci.ncsu.edu/aquaticweeds

http://davesgarden.com/pf/go/160/

The best assurance of having trouble-free plantings is careful plant selection before purchasing, for plants that are not available from local native sources. Plants to be purchased should be examined carefully before accepting them. If they contain contaminants such as duckweed, watermeal, or other potentially invasive species, they should not be accepted.

Communities of aquatic plants establish themselves naturally in conspicuous zones with respect to water depth. From a landward to an open-water direction, these zones consist of communities of emergent species, floating-leaved species, and submersed species. Emergent species root in soil that is continually wet, to sediment underlying water that does not exceed a depth of about $15 \mathrm{~cm}$. Emergent species that are well suited for local conditions include sweet flag, arrowhead, cattails, bulrush, pickerel weed, and spikerush. Floating-leaved species include plants such as water lily, American lotus, and several species of pond weed (Potomogeton spp.). Submersed species that should perform well in the P1 Pond after fish removal include skunkweed, curly pond weed, southern naiad, coon-tail, Myriophyllum, and Elodea, among others. A diverse range of emergent and floating-leaved species capable of performing well in the pond is available commercially. Local sources should be considered for submersed species, because local sources are readily available and these plants will be "pre-adapted" for local conditions.

Largely to facilitate planting, floating-leaved species are typically containerized. These plants are expected to soon escape their containers and spread to other areas of the pond if conditions are suitable. Emergent species can be easily planted by hand with trowels or shovels, or seeded if no surface water is present. For aquatic species, planting is best done early in spring. Grading the shoreline to a more gradual slope would facilitate the colonization of the shoreline with emergent species, which have relatively narrow tolerances for water depth.

Many types of aquatic macrophytes are considered to be "invasive nuisance" species and thus would not be suitable to introduce into the pond. Examples of plants that definitely should not be introduced deliberately into the pond include duckweeds (Lemna spp), water meal (Wolffia sp.), ferny azolla (Azolla pinnata), Hydrilla, Pistia, or Eichornia crassipes. Much web-based guidance is available on species selection. At http://www.weedscience.ncsu.edu/aquaticweeds/comturf/turf.htm, for example, general information is given about emergent species suitable for use in North Carolina:

"Plants such as blue-flag iris, pickerelweed, horsetail or scouring rush, soft rush, several species of spikerushes, lizard's tail, arrow arum, and arrowhead are native, have attractive foliage and/or flowers, are easily established and well adapted to the North Carolina environment, and usually do not become serious problems (i.e., they are easily managed). They all are perennial, over-winter nicely, and are available from in-state aquatic and wetland nurseries." 
The recommended planting method is to introduce a wide variety of species in each zone, focusing first on the shallow areas. A diverse assemblage of plants is similar to natural systems, introduction of multiple species increases the chances of species finding the proper niche (depth, sediments, etc.), and diversity can help prevent nuisance growth of one species. Once established, the plants should grow into deeper areas as well as areas not initially planted.

\section{Plant Selection and Methods}

Emergent Macrophytes. Most species of emergent macrophytes root strongly and, once established, are generally very good at holding space. Usually these types of plants are constrained spatially with respect to water depth, but they can dominate areas where water depth is satisfactory. Advantages resulting from the presence of emergent macrophytes include sediment/soil stabilization; shading of water or sediment by the plants' leaves; and the production of moderately recalcitrant organic matter that can sustain sediment and soil microbial metabolism. Some species of emergent aquatic macrophytes are considered to be invasive and should be avoided. Other species, such as soft rush (Juncus effuses) and cattail (Typha latifolia) are native and will quickly colonize available habitat without planting. The following list of emergent species are examples of species that are considered suitable for use in the P1 Pond.

Arrow arum (Peltandra virginica) is an emergent species that prefers shallow water (a few $\mathrm{cm}$ ) or mud; it might be most appropriate for use in "mud flat" areas that consistently remain wet.

Mud Plantain (Alisma subcordatum) is an emergent species that prefers shallow water (a few $\mathrm{cm}$ ) or mud and is already abundant in upstream waters that enter P1 Pond.

Pickerel weed (Pontederia cordata) is prohibited in Louisiana, but not in Tennessee or surrounding states (http://www.pondsplantsandmore.com/generic $70 . h t m l)$. It also grows well locally.

Broad-leaved arrowhead (Sagittaria latifolia): This species also is present locally and is widespread. It prefers mud yet can grow in several $\mathrm{cm}$ of standing water (http://wisplants.uwsp.edu/scripts/detail.asp?SpCode=SAGLAT).

Many types of emergent macrophytes develop as tough tussocks supported by a compact, dense network of roots and underground energy-storage / reproductive structures (rhizomes, tubers, etc.). Such clumps can be hand-planted with a shovel or trowel in early spring, when the leaves and shoots first start emerging. The emergent aquatic macrophytes recommended here can be planted near the pond's edge; they can thrive in wet soil, where water is continually as deep as $\sim 20 \mathrm{~cm}$ below the soil surface, or in sediment, where water depth does not routinely exceed $\sim 10 \mathrm{~cm}$. The clumps can be spaced as desired; they self-propagate readily and spread horizontally by development of rhizomes, stolons and tubers, filling spaces left between adjacent clumps within a few growing seasons. Seeding with a wetland mix is an option in wet soil areas at the pond margin.

Floating-Leaved Macrophytes. Floating-leaved macrophytes include water lilies, lotus, and a number of relatives. Hardy water lilies (Family Nymphaeaceae; Nuphar and Nymphaea) are rooted (see http://www.victoria-adventure.org/waterlilies/family tree.html) and widespread. The genus Nymphaea, in particular, contains many species and varieties; some of these would be suitable for pond habitats in Tennessee and are available commercially. Some species of Nymphaea, such as $N$. odorata (fragrant water lily) and $N$. mexicana (yellow water lily) can spread quickly; $N$. odorata is found throughout the eastern half of the United States, from Florida to Canada. Fragrant water lily can grow in mucky or silty sediment, in water up to about $2 \mathrm{~m}$ in depth. When managed to form a patchy distribution interspersed with open water, waterlilies can provide excellent habitat for fish. 
Nuphar is closely related to Nymphaea. Nuphar advena (common name, spatterdock) occurs in Tennessee and can grow in water up to a depth of about $2 \mathrm{~m}$ if the water is not turbid. A web site containing useful information about Nuphar is: http://plants.ifas.ufl.edu/nulupic.html.

The American lotus (Nelumbo lutea) has leaves that may be above the water or floating on it. The plant grows in muddy, shallow waters such as lake margins, or in water as deep as $2 \mathrm{~m}$. American lotus occurs throughout the eastern half of United States and Canada. Once established, colonies expand (by rhizome growth) by as much as 15 to $20 \mathrm{~m}$ a year (Hall and Penfound 1944). American lotus grows at depths of up to about $2.5 \mathrm{~m}$, but does best in water 0.6 to $1.8 \mathrm{~m}$ deep. Presumably, initial establishment is in shallow water areas, with subsequent expansion into deeper water. The number of leaves per ha in welldeveloped colonies has been estimated to be as many as 185,000 . This plant is very hardy and prolific. Based on undocumented personal communications, this species was dominant in the P1 Pond prior to grass carp introduction.

Several floating-leaved species of Potamogeton (e.g., P. diversifolius, $P$. illinoensis) also are geographically widespread and suitable to include in the P1 Pond's primary producer community. Floating leaved species of Potamogeton are not readily available from commercial sources but are readily transferable from other ponds on the Oak Ridge Reservation.

When planting floating-leaved emergents, such as water lilies, only containerized plants should be used. Even well-containerized plants will soon escape from their containers and proliferate if environmental conditions are suitable. However, containerization initially is still helpful for two reasons. First, it facilitates initial deployment of the plants. Second, it can allow easier recovery of most of the plant biomass, as much as a year or two after initial deployment, if for some reason the decision is made to eradicate the plant.

Spatterdock (Nuphar lutea var. advena) should be planted from mid-April through May and can grow in USDA zones 3 to 9. Nuphar rhizomes should be placed in clayey soil, near the center of the container, slightly off horizontal, with the growing point just above the soil, pointing across the container. Ideally, containerized water lilies should be placed where the water is 15 to $30 \mathrm{~cm}$ deep; the spacing can be as close as $60-90 \mathrm{~cm}$, but a reasonable rule of thumb is about one plant per 10 square feet. Plants that thrive initially will propagate deeper. Containers used for water lilies should be relatively wide, shallow tubs or baskets.

American lotus (Nelumbo sp.) rhizomes also should be planted in the center of the container. Lotus rhizomes should be handled carefully, for they are brittle and subject to damage. Lotus rhizomes are best planted in large round containers (tubs) and should be covered with about 2-4 inches of soil, keeping the growing tips above soil level. Again, a clayey soil should be used to help keep the rhizomes fixed in a position suitable for good growth. The surface of the soil in the container should be $\sim 5$ to $\sim 10 \mathrm{~cm}$ under water when the rhizome's container has been deployed.

Submersed Macrophytes. Various species of sumbersed macrophytes can become prevalent and abundant in clear-water ponds and lakes. Examples of submersed species that are common locally include Myriophyllum heterophyllum, Isoetes sp., Valisneria americana, Najas sp., Chara sp. (a macroalga), Ceratophyllum, Elodea and Potomogeton spp. Most of these plants root weakly (e.g., Myriophyllum, Elodea, Najas) or lack roots entirely (e.g., Ceratophyllum) and derive most of their nutritional needs directly from the water. Their presence is advantageous for multiple reasons. First, they tend to oxidize surficial sediments, which reduces the flux of materials such as iron and manganese from the sediments to the overlying water. Second, their presence physically reduces access to the sediments by some biota, so sediment resuspension is reduced. Third, the architecture or physical structure of sumbersed macrophyte communities provides spatial refugia for small fish and invertebrates, and surface area for attachment of 
algae, bacteria, protozoans and fungi. Various genera listed here could be added to the P1 Pond. Some of the species unpredictably will out perform others, depending upon chance and highly local conditions, increasing the likelihood of a taxonomically diverse community of submersed species.

Southern naiad (Najas guadalupensis) also might be considered for use in the P1 Pond. Five species of Najas occur in Florida. Southern naiad is widely distributed thoughout the United States and parts of Canada. It reproduces by fragmentation and seed, prefers shallow water, and can form dense monospecific colonies. It also grows in association with other submersed aquatics such as spinyleaf naiad, pondweeds, and muskgrass. Like spinyleaf naiad, reservoir populations of southern naiad may fluctuate dramatically over a period of several years in response to changes in the amount of available light. Southern naiad seems to be more tolerant of turbidity, warm water temperatures, and eutrophication than some of the other native species of Najas. For these reasons, this species has spread in some regions of the United States over the past century. The plant is a valuable waterbirds food and provides habitat and substrate of fish and invertebrates. However, it has not been found in eastern Tennessee, for unknown reasons. A map showing the distribution of Southern niad can be found at:

\section{http://www.efloras.org/object_page.aspx?object_id=11375\&flora_id=1.}

Curly-leaf pondweed (Potamogeton crispus) occurs as an introduced species throughout the United States and can do well under low-light conditions (Stuckey 1979). It also provides good habitat for invertebrates and fish. Curly-leaf pondweed and Chara are both abundant in the P3-P5 ponds, are also in a very shallow area of P1 Pond (Peterson et al. 2005), and are likely to establish themselves at P1 Pond once the grass carp are removed.

Many species are such as Elodea, Myriophyllum, Chara and Ceratophyllum, can be obtained from local sources. An example of a local source would be Lambert Quarry, not far from the ETTP. Working either from a boat or in some cases from shore, a variety of submersed plants can be collected readily by a rope fitted with a plant-hook. The material collected in this manner can be transported fresh to the desired location and planted immediately using a shore-based assembly-line process. Planting can be accomplished by inserting fragments (10 to $20 \mathrm{~cm}$ lengths) into small peat-pots; the fragments are held in place with a clayey sediment. When the fragments have been containerized, they can be loaded on trays into a boat and dropped individually to the sediment surface at the desired locations. A simple planting method similar to this was used successfully to initiate dense populations of submersed macrophytes in experimental ponds at ORNL.

Riparian Planting. Planting of a buffer zone around the pond would help to prevent runoff and limit the use of the pond by geese. The current condition of mowed areas right up the pond's edge is perfect habitat for geese (they can forage on grasses and see potential predators) and exacerbates nutrient loading to the pond.

Riparian planting should include planting of shrubs and a few trees, and use of native warm season grasses. Tall grasses and shrubs are not good habitat for Canada geese, and if present around the pond's edge, will severely limit the pond's use by this species.

\section{Wildlife Management}

In addition to revegetating shore areas to limit use by geese, a small effort to reduce the goose population is recommended for the first two years when reduction in nutrient loading is desirable, and before shore vegetation becomes well established. Nutrient loading is a major water quality concern in the pond (per its negative effects on plants, DO issues, etc.), and geese are a major source of pond nutrients (an estimate of nutrient loading from geese into the pond is provided in the following section). 
Several methods have been recommended for managing geese around ponds (Cruz and Fairchild 2004). These methods include harassment, habitat modification, chemical and natural repellents, and direct population control. Habitat modifications generally are effective at controlling geese. One of the favorite habitats of geese is around ponds surrounded by grassy lawns, where they feed on the grass. Open lawns also provide open habitat, which reduces hiding places for potential predators. Thus, replacing open lawns with vegetative buffer strips (e.g., 6 to $9 \mathrm{~m}$ wide; which might include trees, upland, transitional, and emergent vegetation) would remove a major food source and increase hiding places for potential predators. Establishing a vegetative buffer strip would have the added benefits of reducing erosion, preventing grass clippings from entering the pond in summer, moderating temperature fluctuations the water and using excess nutrients present in the runoff. Strategic placement of fencing would help keep geese away from the water, because geese prefer walking into the water rather than flying. Use of wires with flags across open areas has also been successful in limiting geese flight. Population control via addling of goose eggs is also suggested for the first two years.

\section{Water Quality Manipulations}

One of the most important factors in the successful implementation of the Ecological Management alternative is manipulation of water quality and the biological factors that have the greatest impact potential on water quality (e.g., phytoplankton production, invasive carp). The quality of the water affects the biological characteristics at all trophic levels. When water quality conditions degrade to the point that a change occurs at one trophic level, it will have a cascading and negative effect at other trophic levels. For example, increased nutrient concentrations will increase phytoplankton production. This will lead to increased biomass of planktivores and an increase in organic sediments (i.e., via mortality and the accumulation of dead phytoplankton). If nutrient levels are consistently high, , the magnitude in daily fluctuations in dissolved oxygen (DO) will increase, as will the chance for critically low DO concentrations (i.e., $<5 \mathrm{mg} / \mathrm{L}$ ). By identifying water quality factors that control biological conditions, key water quality and biological characteristics can be altered to achieve the desired ecological conditions.

In its current state, P1 Pond is eutrophic: it has high nutrient concentrations, which contribute to high primary production by phytoplankton and relatively low water clarity (Carlson 1977; Peterson et al. 2005). This condition results in periods of low DO concentrations which, as observed in the summer of 2004, can stress aquatic organisms (Peterson et al. 2005). To achieve the desired ecological state in the pond (i.e., high water clarity, maintenance of suitable DO concentrations, extensive emergent vegetation, and simple fish community), long-term control of water quality is critical. Several initial steps should be taken to change problematic water quality characteristics of the pond. A description of the factors critical to the success of P1 Pond Ecological Management and the options for controlling them follow.

Nutrients. Nutrient control in P1 Pond is one of the most important considerations for successful ecomanipulation. The relatively high concentrations of phosphorus and nitrogen in P1 Pond have resulted in its eutrophication (Peterson et al. 2005).

To reduce nutrient concentrations in P1 Pond, the major sources must be identified. Nutrients can come from runoff from surrounding areas, bottom silt and dead vegetation (e.g., algae), atmospheric deposition, and source waters (e.g., streams, effluent discharges; see Barebo 2002, Lynch 2004, Otterbine Barebo Inc. 2003). Some of the nutrients in runoff come from fertilizers, animal wastes, and grass clippings. Grass clippings in P1 Pond are a seasonal factor, but these enter the water during the summer when environmental conditions (maximum temperatures and solar radiation) maximize their negative effects. Establishing buffer vegetation (shrubs, tall grasses) would reduce nutrient inputs into the water. While mammals such as ground hogs, raccoons and several species of waterbirds use and live around P1 Pond, Canada geese are clearly the most significant contributor to nutrient loading. Manny et al. (1994) conservatively estimated that one goose can contribute $0.49 \mathrm{~g}$ of phosphorus per day to a body of water. 
P1 Pond and its adjacent shores are used extensively by Canadian geese (Efroymson et al. 2005 draft), particularly the shallow east-northeast end of the pond where grasses are maintained up to the pond's edge. Assuming that 50 geese use P1 Pond every day of the year, they would add $\sim 9 \mathrm{~kg}$ of phosphorus to the pond annually. The added nutrients encourage algal production, and as the algae die, they sink to the bottom, where the nutrients are released.

Where controls of nutrient inputs are not sufficient to reduce excess quantities of phosphorus, or if there is a need to hasten the rate of phosphorus removal, aluminum sulfate (alum) can be applied to the pond. This is likely to be needed during the first year prior to vegetation establishment and goose control efforts. Alum binds with orthophosphate to form an insoluble precipitate that settles to the bottom (Fairchild 2004). The precipitate forms a cap on the surface of the sediment which reduces the release of phosphorus from the sediments. Alum addition can lower the $\mathrm{pH}$ in soft-water systems, but products containing buffered alum also are available and these can keep the $\mathrm{pH}$ from decreasing. With the moderately high alkalinity of surface waters near Oak Ridge, even non-buffered alum should not strongly affect either the alkalinity or the $\mathrm{pH}$ in P1 Pond. If the water is to be treated with an algaecide as well, the algaecide should be applied before applying alum (Lind 2005).

Sedimentation. Sediments in ponds come from two sources: internally produced and erosion (Cruz and Fairchild 2004). Sediment inputs from erosion usually make up the largest source of sediments to ponds, and pond sediments that are derived from erosion generally are dominated by inorganic sand, silt, and clay. Sediments produced internally are organic-rich and result from the accumulation of dead biological material such as algae, bacteria, fungi, and terrestrial plants. Excess sediments from either source can negatively affect fish spawning success, reduce pond volume, lower water clarity, and reduce DO concentrations by encouraging anaerobic decomposition. Increasing the clarity of water in the P1 Pond will be important in the success of Ecological Management, because submersed and floating-leaved macrophytes cannot become established if water clarity is limiting.

Several steps can be taken to reduce and control sediment problems in P1 Ponds (Cruz and Fairchild 2004; Otterbine Barebo, Inc. 2003). By reducing nutrient inputs, phytoplankton growth will be reduced. This, in turn, results in less input of organic matter to the sediments. Establishing a vegetative buffer strip also would help reduce inputs of inorganic sediments from erosional sources. Finally, if emergent vegetation (e.g., cattails, bulrush, sweet flag) can be established in the shallow-water zones of the pond, smaller amounts of sediments would enter the pond, and there would be less re-suspension of fine sediments (organic and inorganic).

Suspended sediments can be reduced by applying alum or gypsum (calcium sulfate) (Wilkinson 2002). Such use would be proposed as a temporary solution until vegetation is established.

Algae. Algae exist naturally in all aquatic ecosystems. These simple plants are at the base of the food chain and are a major source of food for primary consumers such as zooplankton, many layer invertebrates, and some species of fish. Algae need light and inorganic nutrients to grow, of which phosphorus is one of the most important (Vandiver 2002). Algae also can be a major source of DO in water bodies. If nutrient levels are excessive, algae can become a nuisance and create various problems, including reduced water clarity, noxious odors, and extreme day-to-night variations in dissolved oxygen concentrations (Otterbine Barebo, Inc. 2003). Some species of freshwater algae are even toxic, and can degrade water quality for fish or livestock. The most effective way of controlling algae is by controlling the inputs of nutrients.

Habitat modification and reduction of nutrient inputs provide long-term solutions for reducing phytoplankton abundance in the P1 Pond, and should be implemented as extensively as possible to increase chances for the long term success of the proposed alternative. Algae control also can be 
accomplished with chemical treatments. Although widely used for controlling extensive algal problems (Vandiver 2002), chemical treatments generally should be used only as a last resort. Because of the high nutrient concentrations in P1 Pond, and because deposition of organic matter has occurred in the pond for many years, the pond's sediments will continue to serve as a major source of phosphorus to the water column. Thus, some chemical treatment probably will be needed to reduce algal abundance. Lowering the abundance of phytoplankton in the pond will increase water clarity and thus, enhance growth of macrophytes. Several chemical options could be used to control algae in P1 Pond; some of these are summarized in Table 4. Because oxygen will be consumed as the killed algae decompose, only one-half to one-third of the pond should be treated at a time.

Copper-based algaecides generally are very effective and are used widely in ponds (Fairchild 2004). The use of copper-based compounds to control algae should be carefully applied as high concentration can be toxic to sensitive aquatic animals and copper can persist (although not likely biologically available in P1 Pond). Except under extreme water quality conditions or severe changes in water quality (e.g., drastically lowered $\mathrm{pH}$ or alkalinity), most of the copper will remain adsorbed to organic materials and to the surfaces of clay and mineral particles in the sediment. In fact, copper will precipitate from solution in very hard water, which can reduce its effectiveness. Chelated copper algaecides are more expensive, but are less sensitive to water hardness. They also remain in solution longer and usually control algae better. The $\mathrm{pH}$ of the water in $\mathrm{P} 1 \mathrm{Pond}$ is normally well above 7.0, and local water bodies typically have moderate levels of alkalinity $\left(115-175 \mathrm{mg} / \mathrm{L}\right.$ as $\mathrm{CaCO}_{3}$; Peterson et al. 2005, Smith et al. 2005).

Endothall formulations belong to the dicarboxylic acid chemical class of contact herbicides, but they provide only moderate control of algae (Extension Toxicology Network 1995, Masser et al. 2001). Two salt forms are used for control of plants in ponds, but the mono-(N,N-dimethylalkylamine) salt (Hydrothol $囚$ ) is typically used for controlling algae. However, it also is toxic to some macrophytes. Toxicity of Hydrothol ${ }^{\circ}$ is moderate to many species of fish and invertebrates (Masser et al. 2001), and it has a short half-life of $\sim 7$ days (Extension Toxicology Network 1995).

Diaquat dibromide is a general-use herbicide for the control of algae, aquatic macrophytes, and terrestrial vegetation (Extension Toxicology Network 1993). Diaquat is not very toxic to aquatic animals, breaks down rapidly, and does not bioconcentrate. Diaquat binds rapidly and tightly to clay particles, so it is not effective in muddy water (Masser et al. 2001). Even under good conditions, it provides only moderate control for filamentous algae and poor control for planktonic algae.

Inert dyes block the wavelengths of light needed by algae to grow (Fairchild 2004). If applied at the right time of the year (i.e., during the beginning of the growing season), algae can be controlled effectively with inert dyes. However, inert dyes are not effective in shallow waters (i.e., $<2 \mathrm{ft}$ ), and should only be used when there are no outlets to other bodies of water (Ohio School of Natural Resources 1998, Otterbine Barebo, Inc. 2003). Another algicide, simazine, is no longer approved for use in the United States because it is a suspected carcinogen (Kelly 1998).

\section{Preventive Actions}

Preventive actions include creation of a barrier to fish movement from Poplar Creek into the P1 Pond, fish management actions in the upstream ponds that feed into the P1 Pond to prevent migration of undesirable species, construction of a fence to help prevent use of the pond by geese, and expansion of the riparian zone to control erosion and discourage pond use by geese. 
Table 4. Possible chemical treatments for planktonic algae.

\begin{tabular}{|c|c|}
\hline Algicide Active Ingredient & Application Information \\
\hline $\begin{array}{l}\text { Copper (e.g., } \mathrm{CuSO}_{4} ; \\
\left.\text { Cutrine-Plus }{ }^{\circledR}\right)\end{array}$ & $\begin{array}{l}\text { Copper sulfate is the most commonly used algaecide and } \\
\text { provides effective control. Copper sulfate products can be } \\
\text { applied as liquid or granululated formulations. Liquid treatments } \\
\text { are used for entire water column; granular treatments are used for } \\
\text { spot treatments and problems on the bottom. Chelated } \\
\text { formulations (e.g., Cutrine-Plus) are less sensitive to water } \\
\text { hardness. The entire pond should not be treated in single } \\
\text { application, because decomposing algae can lower the levels of } \\
\text { dissolved oxygen. To avoid anoxic conditions, divide } \\
\text { application into } 3 \text { or } 4 \text { with } ~ 10 \text { days between each. Apply when } \\
\text { the air temperature is }<80^{\circ} \mathrm{F} \text { and the water temperature is }>60^{\circ} \mathrm{F} \text {. } \\
\text { The application rate of copper sulfate products depends on } \\
\text { alkalinity. Bluestone copper sulfate is applied at a rate of } \\
2.0 \text { lb/acre-ft at alkalinity of } 100 \text { to } 149 \text { mg/L, and } 2.8 \mathrm{lb} / \mathrm{acre-ft} \\
\text { at alkalinity of } 150 \text { to } 200 \mathrm{mg} / \mathrm{L} \text {. Chelated copper products such } \\
\text { as Cutrine Plus should be applied at a rate of } 0.6 \text { gal/acre-ft for } \\
\text { most algae. The use of copper-based compounds to control algae } \\
\text { should be carefully applied as high concentration can be toxic to } \\
\text { sensitive aquatic animals and copper can persist (although not } \\
\text { likely biologically available in P1 Pond). }\end{array}$ \\
\hline $\begin{array}{l}\text { Diquat (e.g., Reward } \AA \text {, } \\
\text { Weedtrine-D }(\text { ) }\end{array}$ & $\begin{array}{l}\text { Low to moderate effectiveness for algal control. Can't be used in } \\
\text { muddy water due to binding with particles; water use should be } \\
\text { restricted for } \sim 10 \text { days after use. Binds rapidly and firmly with } \\
\text { sediments, and decomposes via microbial degradation and with } \\
\text { exposure to light. Products such as Reward are applied at a rate } \\
\text { of } \sim 2 \mathrm{gal} / \text { acre-ft. }\end{array}$ \\
\hline Endothall (e.g., Hydrothol®) & $\begin{array}{l}\text { Contact herbicide. The action of endothol products is not } \\
\text { affected by suspended solids. Liquid formulations are applied at } \\
\text { a rate of } 0.6 \text { to } 2.2 \text { pints/acre-foot, and are best for general } \\
\text { treatment. Granule application is suggested for spot treatments. } \\
\text { Endothall degrades relatively rapidly (half-life } \sim 7 \text { days) in } \\
\text { surface waters. Can be quite toxic to aquatic animals. Amine } \\
\text { salts are more toxic to biota than inorganic salts. }\end{array}$ \\
\hline Simazine (e.g., Aquazine) & $\begin{array}{l}\text { Simazine products are no longer approved by the U.S. } \\
\text { Environmental Protection Agency for aquatic use because } \\
\text { simazine is a suspected carcinogen (Kelly 1998). }\end{array}$ \\
\hline $\begin{array}{l}\text { Inert dyes (e.g., Aquashade, } \\
\text { Aquashadow) }\end{array}$ & $\begin{array}{l}\text { Works by attenuating wavelengths of light needed for } \\
\text { photosynthesis. The effectiveness of dyes varies, but is usually } \\
\text { most effective at the beginning of the growing season. However, } \\
\text { they are not effective in water that is }<2 \mathrm{ft} \text { deep, nor are they } \\
\text { effective for floating algae. Dyes should be used only when there } \\
\text { are no outlets from the body of water. }\end{array}$ \\
\hline
\end{tabular}


As part of the Ecological Management alternative, preventive actions are designed to limit repopulation of the pond by undesirable fish and geese. The preventive actions have a high probability of success: as designed, the P1 barrier would prevent any connection of water between Poplar Creek and the P1 Pond even under a 500-year flood. Fish in upstream ponds also can be manipulated readily using a combination of selective removal methods and rotenone treatments. The ponds are relatively small and contain a relatively small population of undesirable species based on 1990s surveys (largemouth bass). A short fence placed along the edge between the vegetated buffer zone and mowed areas will prevent movement of geese into the pond and also be aesthetically pleasing.

\section{RECOMMENDED ACTIONS}

Risk reduction to target remediation levels of PCBs in fish is obtainable using Ecological Management actions. Similar to conventional options such as capping, risk reduction is achieved by pathway interdiction. Species posing the greatest risk to humans and ecological receptors, largemouth bass and gizzard shad, are removed from the system and will pose no risks to humans or wildlife after removal. Pond bioaccumulation processes will be further minimized by Ecological Management actions that prevent future bioaccumulation to unacceptable levels. Once the system has been changed to a stable, highly vegetated pond, the system will not be favorable for sustaining substantial populations of shad or large bass, even if these species were able to obtain access. Preventive actions such as fish barriers and the isolating effects of dams also will ensure that undesirable fish cannot reenter the pond.

The specific recommended actions can be divided into the following major actions:

- Fish management

- Vegetation management

- Wildlife management

- Water quality manipulations

- Preventive actions

Based on the analysis of various options (Proposed Actions Section), the following specific actions are recommended. The recommended actions include all potential actions that are deemed to be beneficial in reducing risks. Some actions are critical to the strategy (e.g., P1 fish management, vegetation planting, and initial water quality manipulation), while other actions are less so. For example, actions such as follow-up algaecide treatments, goose fencing, or bluegill stocking, may not be needed but are included as potential options in this alternative. Some selection of management options is possible depending on the acceptable level of uncertainty. The recommended strategy includes multiple and sometimes redundant actions to ensure rapid and successful conversion to the desired end state.

Recommended Fish Management Actions. The preferred option for Ecological Management of the P1 Pond involves a major re-structuring of the fish community. In general, the strategy is to temporarily remove desirable fish such as sunfish, conduct rotenone treatments to remove high risk and undesirable fish such as carp and shad, and then return the desirable fish back into the pond. A multi-step process is proposed for implementation with fish management actions occurring first at P4 and P5, then P3, then P1 Pond (the P3-P5 actions are considered preventive actions in the described strategy). Using multiple boat electrofishing units, desirable fish such as sunfish and small minnows will be removed from each pond and held in nearby fish holding pens.

When a large enough number of fish have been obtained for restocking, the ponds will undergo rotenone treatment. This chemical is a widely used and highly effective tool in pond management to eliminate unwanted or poorly structured fish communities effective. Time of year greatly affects the 
effectiveness of the rotenone application. With cooler water temperatures and shorter daylight periods, it remains active much longer, perhaps as long as a month. At temperatures near $75^{\circ} \mathrm{F}$, rotenone will break down in three to four days upon exposure to sunlight. It is also important to control water flow in and out of the pond. Water entering the treated pond will reduce rotenone concentrations and effectiveness, and treated water exiting the pond can kill non-target fish communities in downstream areas. For these reasons, rotenone application is suggested for late summer or early fall, when rainfall is generally lowest and water temperatures increase the effectiveness of rotenone.

For the P1 Pond, it would be useful to lower the water in the P1 Pond to centralize the fish population and assist in fish collection as well as rotenone treatment, and to assist in controlling water discharges to Poplar Creek. Modification of the P1 dam to a standpipe control design is proposed as part of all alternatives at P1 Pond (Bill Barton, pers. comm.).

The fish management actions proposed herein will require a large number of boats, including specialized electrofishing boats, a large number of holding pens, nets, fish storage tanks or large containers, and adequate quantities of rotenone. The fish management actions are labor intensive, and designed to put the maximum effort into a short period of time to minimize fish stress (in the case of desirable species) and avoid a longer-term presence of dead fish. Dead fish from the rotenone surveys will need to be buried. A suitable location is available on the east shore of P3 for P3-P5 fish. At the P1 Pond, a suitable location is available at the southwest end of the pond, between the pond and Burchfield Road. A backhoe or similar equipment will be needed to dig a large hole for the fish. Regulatory approval for fish burial on-site also must be obtained.

Recommended Vegetation Management. The general strategy for establishing vegetation in the pond is to populate the shallow areas, particularly the northeast end near SD 100, within the SD 490 arm, the P3 Pond arm, and the north side near the dam. The vegetation would expand from those areas over time. Vegetation planting should be conducted in the spring of the first year after all the grass carp and other undesirable fish species have been removed from the pond and water clarity is ensured using chemical treatment. Modest grading of shore areas before planting also would enhance establishment of emergent and aquatic plants.

Based on an estimated 600 feet of shoreline and riparian area to be vegetated, and assuming the requested species are available, the following planting regime is recommended: planting/placing 500 containerized individuals of two floating-leaf species (Nuphar, Nelumbo) in the 6-inch to 1.5-foot depth zone, including 500 seeds of the same or similar floating-leaf, water-lily species; 300 individuals each of five species of emergent plants (1500 total) using small plants or plugs, in the (-2) to 6-inch waterdepth zone (e.g., mud plantain, arrow head, lizard tail, pickerel rush, sweet flag, spike rush, etc.), 500 sprigs of shrubby species in wet onshore soil (e.g., silky dogwood, willow, buttonbush), with approximately 15 pounds of herbaceous wetland mix to be broadcast on wet shore, and 20 trees on the upland margin. Native warm-season grasses also should be planted throughout the upland areas. The emergent plants should be placed on 18- to 24-inch centers; the shrubby species should be planted in groups of three to five, with the groups being more or less randomly distributed over the area of consideration. Submersed species should be obtained from local waterbodies where possible, and transported directly to the pond for planting.

In addition to intensive planting in year 1, close attention is advised for planting in the spring of the second year, especially in regard to the establishment of aquatic plants: this effort would be used to (1) fill in gaps in the event that some plants that were planted the first year did not survive, and (2) extend the vegetation to other suitable locations around the pond. Riparian planting is not anticipated in year 2 . 
Recommended Wildlife Management. There are many options to control geese, but the preferred actions for the P1 Pond include riparian vegetation management (which provides multiple benefits), the use of flagged wire in suitable locations, short-term population control by addling eggs, and strategic placement of fencing (a preventive action). Control efforts would continue for two years, after which riparian cover should be sufficient to discourage geese use and allow aquatic vegetation in the pond to become well established.

Recommended Water-Quality Manipulations. Before placing aquatic plants in the pond, initial treatment of the pond with an algaecide and alum are recommended to enhance water clarity. The initial application should be completed near the start of the growing season, when water temperatures reach $60-65^{\circ} \mathrm{F}(\sim$ April 1$)$. The initial recommended treatment of the entire pond is copper sulfate, which, upon careful application, should be the least detrimental to aquatic life. Due to the persistence of copper, follow up algal treatments, if necessary, could include the liquid form of endothall-based algaecide, Hydrothol ${ }^{\circledR}$ 191 (Ohio School of Natural Resources 1998). Because of the relatively high rate of primary production measured in P1 Pond in 2004, the maximum application rate of 2.2 pints/acre-foot is recommended for each application, although less could be needed if only spot treatment is necessary. At 111 acre-feet, 31 gallons of Hydrothol ${ }^{\circledR}$ normally would be needed for a single treatment. Hydrothol ${ }^{\circledR} 191$ is applied uniformly across the pond surface by spraying.

The use of alum will help reduce the concentration of phosphorus in the water column, bind phosphorus in the sediments, and increase water clarity. If inputs of phosphorus and suspended solids from storm drains and P3 Pond are low, only one application of alum may be needed. The recommended application of alum is $40 \mathrm{lb} / \mathrm{acre}-\mathrm{ft}$ ( 4,440 pounds for the entire pond) for a single treatment. Alum can be spread by hand or sprayed as a slurry.

To monitor the conditions in the pond and the need for additional treatments, Secchi depth, phosphorus, chlorophyll $a$, and total suspended solids measurements should be made. The desired goal of water clarity forP1 Pond is at least $1.5 \mathrm{~m}$. The target concentration for total phosphorus is $<10 \mu \mathrm{g} / \mathrm{L}$, with a target for chlorophyll $a$ of $<25 \mu \mathrm{g} / \mathrm{L}$.

Recommended Preventive Actions. Preventive actions are intended to help ensure the long-term viability of the newly remediated site. Among these would be preventing any influences of fish or large numbers of geese from outside the system. Although probably not critical to the success of the Ecological Management alternative, these actions can be deemed "additional safe-guards". Recommended preventive actions include creating a barrier to fish movement from Poplar Creek into the P1 Pond, fish management actions in the upstream ponds that feed into the P1 Pond to prevent any migration of undesirable species, and construction of a fence to help prevent use of the pond by geese. Establishment of vegetation in the pond, which once established is extremely difficult to change, could also be considered a preventive action, as this type of pond community is not conducive to the success of some undesirable fish species if they were present (e.g., open-water species such as shad). Establishment of additional riparian vegetation is also recommended.

Currently, high water levels that would allow fish to move between Poplar Creek and the P1 Pond are extremely rare events. Anecdotal evidence suggests the last time of such an event was in the 1980s. The construction of a fish barrier would ensure that fish cannot enter the pond from Poplar Creek, and there is little or no opportunity for fish to modify the P1 Pond system (note: only the unlikely event of a large influx of grass carp would be deemed a significant enough event to modify the pond dynamics once vegetation is well established). The simplest and most effective way to establish a fish barrier between the P1 Pond and Poplar Creek is to add an approximately 4-inch asphalt layer on top of the existing Burchfield Road (Bill Barton, pers. comm.). This addition would appear to top the 500-year flood line and prevent a fish pathway between the two waters. 
Manipulation of fish in P3-P5 also is recommended (see recommended fish management actions for details). Early surveys will determine the extent of any undesirable fish from these waters (expected to be bass only, perhaps also common carp). The recommended action assumes the worst case and a full manipulation of the fish population is needed (i.e., all undesirable fish are removed through the use of rotenone).

Placing a 3-ft high, rough-cut wood fence along the edge between the vegetated buffer zone and mowed areas will restrict geese from the pond and also be aesthetically pleasing. A complete barrier such as wood slats is not needed, because any fence, in combination with dense vegetation, is deemed effective.

\section{NATURAL RESOURCES BENEFITS}

Numerous natural resources benefits are associated with the Ecological Management alternative. Many of these have been evaluated for current conditions of the P1 Pond and the no-action alternative (see Efroymson et al. $2005 \mathrm{draft}$ ). Although the fish community diversity will be reduced substantially, and the value added to the fish community from connectivity to other water bodies will be reduced, the habitat value will be improved in other ways (Table 5). These benefits include:

- the introduction of native species of emergent and submersed macrophytes (not evaluated in Efroymson et al. 2005 draft or Table 5);

- an anticipated increase in diversity and abundance of waterbirds;

- an increase in wetland area;

- an increase in diversity of benthic invertebrates;

- the likely increase in favorable habitat (and abundance and diversity) and buffer area for amphibians;

- the likely increase in buffer area for reptiles;

- the removal of non-native fish such as common carp and grass carp;

- the removal and long-term limitation of non-native Asiatic clam populations; and

- the elimination of a pathway for potential colonization by invasive zebra mussels

In addition, the removal of nuisance Canada geese and the improvement in the aesthetic value of water clarity may be deemed improvements in ecological services.

Because the Ecological Management alternative will result in an artificially constrained system, indirect measures of habitat value in Table 5 may no longer indicate species diversity and habitat-use value. For example, high habitat complexity does not mean that fish diversity is high. During the monitoring phase for this alternative, it will be important to use direct field measures of diversity. 
Table 5. Habitat valuation results for current and future conditions, estimated for $\mathbf{5 0}$ years following implementation of the Ecological Management alternative. Habitat value scoring criteria and scores for current conditions are from Efroymson et al. (2005 draft).

\begin{tabular}{|c|c|c|c|}
\hline Taxa & Metric & $\begin{array}{c}\text { Habitat Value Score for } \\
\text { Current Conditions }\end{array}$ & $\begin{array}{c}\text { Habitat Value Score for } \\
\text { Future Conditions }\end{array}$ \\
\hline \multirow[t]{7}{*}{ Fish } & Taxa richness & $\begin{array}{l}\text { Medium. } 16 \text { species were } \\
\text { observed in samples made in } \\
\text { August } 2004 \text {. }\end{array}$ & $\begin{array}{l}\text { Low. Fewer than } 10 \\
\text { species will be present. }\end{array}$ \\
\hline & $\begin{array}{l}\text { Taxa richness- } \\
\text { Lepomid species }\end{array}$ & $\begin{array}{l}\text { High. } 4 \text { of these species were } \\
\text { observed in samples made in } \\
\text { August } 2004 \text {, indicating a high } \\
\text { quality littoral zone. }\end{array}$ & $\begin{array}{l}\text { High. Presence of } \\
\text { Lepomid species will be } \\
\text { maintained. }\end{array}$ \\
\hline & $\begin{array}{l}\text { Number of } \\
\text { sensitive species }\end{array}$ & $\begin{array}{l}\text { Medium. One sensitive } \\
\text { species, spotted sucker, was } \\
\text { observed in samples taken in } \\
\text { August } 2004 \text {. }\end{array}$ & $\begin{array}{l}\text { Low. Sensitive species } \\
\text { will not remain in the } \\
\text { pond. }\end{array}$ \\
\hline & $\begin{array}{l}\text { Dissolved oxygen } \\
\text { concentrations }\end{array}$ & $\begin{array}{l}\text { Medium to high. On one of } \\
\text { two sample dates in September } \\
\text { 2004, dissolved oxygen } \\
\text { concentrations in the water } \\
\text { column were below } 5.5 \mathrm{mg} / \mathrm{L} \\
(4.8 \mathrm{mg} / \mathrm{L}) \text { at the P1 Pond dam, } \\
\text { and it is possible that } \\
\text { concentrations are below the } \\
\text { water quality criterion for long } \\
\text { periods during the summer. }\end{array}$ & $\begin{array}{l}\text { Medium to high. } \\
\text { Dissolved oxygen } \\
\text { concentrations in the } \\
\text { water column should be } \\
\text { at least as high as current } \\
\text { levels but may improve } \\
\text { with established } \\
\text { vegetation I the pond. }\end{array}$ \\
\hline & $\begin{array}{l}\text { Number of non- } \\
\text { native or invasive } \\
\text { species-fish }\end{array}$ & $\begin{array}{l}\text { Low. One non-North } \\
\text { American species, common } \\
\text { carp, was observed in samples } \\
\text { taken in August } 2004 \text {. } \\
\text { Common carp and grass carp } \\
\text { were collected in BMAP } \\
\text { sampling efforts in } 2005 \text {. }\end{array}$ & $\begin{array}{l}\text { High. Nonnative species } \\
\text { will all be removed from } \\
\text { the pond. }\end{array}$ \\
\hline & $\begin{array}{l}\text { Abundance of rare } \\
\text { species-fish }\end{array}$ & $\begin{array}{l}\text { Low. No rare fish species are } \\
\text { present. }\end{array}$ & $\begin{array}{l}\text { Low. No rare fish } \\
\text { species will be present. }\end{array}$ \\
\hline & $\begin{array}{l}\text { Presence of } \\
\text { movement corridor }\end{array}$ & $\begin{array}{l}\text { Medium. The pond is } \\
\text { accessible by downstream fish. }\end{array}$ & $\begin{array}{l}\text { Low. The pond will not } \\
\text { be accessible by } \\
\text { downstream fish. }\end{array}$ \\
\hline $\begin{array}{l}\text { Benthic } \\
\text { invertebrates }\end{array}$ & $\begin{array}{l}\text { Ambient dissolved } \\
\text { oxygen } \\
\text { concentrations }\end{array}$ & $\begin{array}{l}\text { Medium but uncertain. On } \\
\text { one of two sample dates in } \\
\text { September 2004, dissolved } \\
\text { oxygen concentrations in the } \\
\text { water column were below } 5.0 \\
\mathrm{mg} / \mathrm{L}(4.8 \mathrm{mg} / \mathrm{L}) \text { at the P1 } \\
\text { Pond dam, and it is likely that } \\
\text { concentrations are below the } \\
\text { invertebrate threshold for slight } \\
\text { impairment for long periods } \\
\text { during the summer, especially } \\
\text { close to the sediments. }\end{array}$ & $\begin{array}{l}\text { Medium but uncertain. } \\
\text { Dissolved oxygen } \\
\text { concentrations near } \\
\text { sediments will probably } \\
\text { remain near the } \\
\text { invertebrate threshold for } \\
\text { slight impairment. }\end{array}$ \\
\hline
\end{tabular}




\begin{tabular}{|c|c|c|c|}
\hline Taxa & Metric & $\begin{array}{c}\text { Habitat Value Score for } \\
\text { Current Conditions }\end{array}$ & $\begin{array}{c}\text { Habitat Value Score for } \\
\text { Future Conditions }\end{array}$ \\
\hline & $\begin{array}{l}\text { Presence of non- } \\
\text { native or invasive } \\
\text { species }\end{array}$ & $\begin{array}{l}\text { Low. The pond has not been } \\
\text { surveyed for shellfish. } \\
\text { However, Asiatic clams have } \\
\text { been observed. }\end{array}$ & $\begin{array}{l}\text { Medium to high. Asiatic } \\
\text { clams will likely be killed } \\
\text { in the pond during } \\
\text { drawdown for rotenone } \\
\text { treatment, and future } \\
\text { water quality conditions } \\
\text { may limit its } \\
\text { repopulation. }\end{array}$ \\
\hline $\begin{array}{l}\text { Fish and } \\
\text { invertebrates }\end{array}$ & $\begin{array}{l}\text { Complexity of } \\
\text { habitat structure }\end{array}$ & $\begin{array}{l}\text { High. This pond has woody } \\
\text { debris, root wads, undercut } \\
\text { banks, boulders, gravel, } \\
\text { emergent vegetation, } \\
\text { overhanging vegetation, } \\
\text { shallows }(<0.3 \mathrm{~m} \text { depth), and } \\
\text { deep areas ( }>3 \mathrm{~m} \text { depth), but } \\
\text { not cobble, sand, or aquatic } \\
\text { vegetation. Therefore the score } \\
\text { is } 9 \text { of } 12 \text { characteristics. }\end{array}$ & $\begin{array}{l}\text { High. This pond will } \\
\text { continue to have woody } \\
\text { debris, root wads, } \\
\text { undercut banks, boulders, } \\
\text { gravel, emergent } \\
\text { vegetation, overhanging } \\
\text { vegetation, shallows } \\
\text { ( }<0.3 \mathrm{~m} \text { depth), and deep } \\
\text { areas ( }>3 \mathrm{~m} \text { depth), as } \\
\text { well as aquatic } \\
\text { vegetation. Therefore the } \\
\text { score is } 10 \text { of } 12 \\
\text { characteristics. }\end{array}$ \\
\hline Amphibians & $\begin{array}{l}\text { Presence of } \\
\text { shallow areas for } \\
\text { amphibian } \\
\text { reproduction }\end{array}$ & $\begin{array}{l}\text { Low to medium. In general, } \\
\text { the pond has few shallow zones } \\
\text { that cannot be accessed by fish. } \\
\text { However, there are a few } \\
\text { floodplain pools at the north } \\
\text { and southwest end of the pond. }\end{array}$ & $\begin{array}{l}\text { Medium. The pond } \\
\text { should have more shallow } \\
\text { zones for amphibian } \\
\text { reproduction, though } \\
\text { many of these will be } \\
\text { accessible by fish. }\end{array}$ \\
\hline & Adjacent habitat & $\begin{array}{l}\text { Low to Medium. With the } \\
\text { exception of small areas to the } \\
\text { southwest and north, the } \\
\text { combination of mowing and } \\
\text { roads surrounding the wetlands } \\
\text { and pond provides very little } \\
\text { buffer area for amphibians. }\end{array}$ & $\begin{array}{l}\text { Medium to high. The } \\
\text { additional wetland and } \\
\text { forested riparian zone and } \\
\text { reduction of mowed area } \\
\text { should provide additional } \\
\text { buffer area for } \\
\text { amphibians. }\end{array}$ \\
\hline Reptiles & Adjacent habitat & $\begin{array}{l}\text { Low to Medium. Except for } \\
\text { small areas to the southwest } \\
\text { and north, the combination of } \\
\text { mowing and roads surrounding } \\
\text { the wetlands and pond provides } \\
\text { very little buffer area for } \\
\text { reptiles. }\end{array}$ & $\begin{array}{l}\text { Medium. There will be } \\
\text { additional buffer area } \\
\text { around wetlands that } \\
\text { should amount to a } \\
\text { distance of at least } 127- \\
289 \mathrm{~m} \text { surrounding } 25 \% \text { - } \\
75 \% \text { of wetland areas at } \\
\text { site, or to a distance of at } \\
\text { least } 80 \mathrm{~m} \text { surrounding at } \\
\text { least } 75 \% \text { of wetland } \\
\text { areas at the site. }\end{array}$ \\
\hline
\end{tabular}




\begin{tabular}{|c|c|c|c|}
\hline Taxa & Metric & $\begin{array}{l}\text { Habitat Value Score for } \\
\text { Current Conditions }\end{array}$ & $\begin{array}{c}\text { Habitat Value Score for } \\
\text { Future Conditions }\end{array}$ \\
\hline \multirow[t]{3}{*}{ Waterbirds } & Taxa richness & $\begin{array}{l}\text { High. } 12 \text { of } 15 \text { waterbird } \\
\text { species observed during } \\
\text { surveys at ETTP in } 2004 \text { were } \\
\text { observed at the pond } \\
\text { (Appendix B). }\end{array}$ & $\begin{array}{l}\text { High. Waterbirds } \\
\text { diversity should increase } \\
\text { even more following the } \\
\text { discouragement of geese. }\end{array}$ \\
\hline & $\begin{array}{l}\text { Presence of } \\
\text { rookery }\end{array}$ & $\begin{array}{l}\text { Low to medium. A } \\
\text { waterbirds rookery is not } \\
\text { present in the immediate } \\
\text { vicinity. }\end{array}$ & $\begin{array}{l}\text { Uncertain. With } \\
\text { increased waterbirds and } \\
\text { less mowing, a rookery is } \\
\text { a possibility. }\end{array}$ \\
\hline & $\begin{array}{l}\text { Presence of } \\
\text { movement } \\
\text { corridor-avian } \\
\text { piscivores }\end{array}$ & $\begin{array}{l}\text { High. The ETTP site has the } \\
\text { largest abundance and diversity } \\
\text { of avian piscivores on the Oak } \\
\text { Ridge Reservation and the } \\
\text { highest density of water bodies, } \\
\text { including Mitchell Branch, the } \\
\text { K-901 pond, the P1 Pond, } \\
\text { Poplar Creek, and the Clinch } \\
\text { River. A heron rookery is } \\
\text { located on Poplar Creek. }\end{array}$ & $\begin{array}{l}\text { High. The waterbirds } \\
\text { movement corridor } \\
\text { should be unchanged. }\end{array}$ \\
\hline Bats & $\begin{array}{l}\text { Presence of rare } \\
\text { species }\end{array}$ & $\begin{array}{l}\text { High. Gray bats (as well as } \\
\text { three more common species) } \\
\text { observed in Anabat survey } \\
\text { conducted in August } 2004 \\
\text { (Appendix C). }\end{array}$ & $\begin{array}{l}\text { High but uncertain. } \\
\text { There is no reason to } \\
\text { believe that gray bats will } \\
\text { not continue to forage } \\
\text { over the pond. }\end{array}$ \\
\hline \multirow[t]{2}{*}{$\begin{array}{l}\text { Wetland } \\
\text { vegetation } \\
\text { and } \\
\text { community }\end{array}$} & $\begin{array}{l}\text { Presence of rare } \\
\text { community-- } \\
\text { wetlands }\end{array}$ & $\begin{array}{l}\text { High. A forested wetland seep } \\
\text { is located at the south-west side } \\
\text { of the pond. Floodplain pools } \\
\text { are also found along the north } \\
\text { end of the pond. }\end{array}$ & $\begin{array}{l}\text { High. Additional } \\
\text { wetlands will be created. }\end{array}$ \\
\hline & $\begin{array}{l}\text { Riparian wetland } \\
\text { coverage, relative } \\
\text { to Southern } \\
\text { Appalachian } \\
\text { regional average }\end{array}$ & $\begin{array}{l}\text { High. Riparian wetland } \\
\text { coverage is much }>2 \% \text { (Fig. 6). }\end{array}$ & $\begin{array}{l}\text { High. Riparian wetland } \\
\text { coverage will continue to } \\
\text { be }>2 \% \text {. }\end{array}$ \\
\hline \multirow[t]{2}{*}{$\begin{array}{l}\text { Riparian } \\
\text { vegetation }\end{array}$} & $\begin{array}{l}\text { Forested riparian } \\
\text { coverage, relative } \\
\text { to Southern } \\
\text { Appalachian } \\
\text { regional coverage }\end{array}$ & $\begin{array}{l}\text { Low. Very little of the pond } \\
\text { riparian zone is forested, } \\
\text { certainly }<60 \% \text {. }\end{array}$ & $\begin{array}{l}\text { High. Over } 60 \% \text { of the } \\
\text { pond riparian zone will be } \\
\text { forested. }\end{array}$ \\
\hline & $\begin{array}{l}\text { Forested riparian } \\
\text { coverage, relative } \\
\text { to Ridge and } \\
\text { Valley regional } \\
\text { coverage }\end{array}$ & $\begin{array}{l}\text { Low. Very little of the pond } \\
\text { riparian zone is forested, } \\
\text { certainly }<30 \% \text {. }\end{array}$ & $\begin{array}{l}\text { High. Over } 30 \% \text { of the } \\
\text { pond riparian zone will be } \\
\text { forested. }\end{array}$ \\
\hline
\end{tabular}




\section{REFERENCES}

APHA (American Public Health Association). 1995. Standard Methods for the Examination of Water and Wastewater. $19^{\text {th }}$ Edition. American Public Health Association, Washington, DC.

Barclay, R. M. R. and R. M. Brigham. 1994. Constraints on optimal foraging: a field test of prey discrimination by echolocating insectivorous bats. Animal Behavior 48:1013-1021.

Barebo, C. 2002. Clean water: your management signature. http://www.igin.com/Irrigation/0902cleanwater.html

Best, T. L., B. A. Milam, T. D. Haas, W. S. Cvilikas, and L. R. Saidak. 1997. Variation in diet of the gray bat (Myotis grisescens). J. Mammalogy 78:569-583.

Best, E. P. H., S. L. Sprecher, S. L., Larson, H. L., Fredrickson, and D. F. Bader. 1999. Environmental behavior of explosives in groundwater from the Milan army ammunition plant in aquatic and wetland plant treatments. Removal, mass balances and fate in groundwater of TNT and RDX. Chemosphere 38:33833396.

Campanella, B. F., C.Bock, and P. Schroder. 2002. Phytoremediation to increase the degradation of PCBs and PCDD/Fs - Potential and limitations. Environ. Sci. Poll. Res. 9:73-85.

Carlson, R. E. 1977. A trophic state index for lakes. Limnology and Oceanography 22:361-369

Chekol, T., L. R.Vough, and R. L. Chaney. 2004. Phytoremediation of polychlorinated biphenylcontaminated soils: the rhizosphere effect. Environ. Internat. 30:799-804.

Cruz, J. and G. W. Fairchild. 2004. Ecology and management of small ponds. West Chester University, West Chester, Pennsylvania. http://darwin.wcupa.edu:16080/ponds/index.html

De Souza, M. P., C. P. A. Huang, N. Chee, N.Terry. 1999. Rhizosphere bacteria enhance the accumulation of selenium and mercury in wetland plants. Planta 209: 259-263.

DOE (U.S. Department of Energy). 2005. 2005 Remediation Effectiveness Report for the U.S. Department of Energy Reservation, Oak Ridge, Tennessee. DOE/OR/01-2211. U.S. Department of Energy, Oak Ridge, TN.

Dykyjová, D. and J. Květ (eds). 1978. Pond Littoral Ecosystems: Structure and Functioning. Ecological Studies 28, Springer-Verlag, Berlin, Germany.

Efroymson, R. A., M. J. Peterson, N. R. Giffen, M. G. Ryon, J. G. Smith, W. K. Roy, C. J. Welsh, D. L. Druckenbrod, W. W. Hargrove, and H. D. Quarles. 2005 draft. Investigating Habitat Value in Support of Remedial Decisions: A Case Study of Six Sites at the East Tennessee Technology Park.

EPA (U.S. Environmental Protection Agency). 1996. 40 CFR Part 132. Proposed Revisions to the Polychlorinated Biphenyl Criteria for Human Health and Wildlife for Water Quality Guidance for the Great Lakes System. Federal Register 61:54748-54756 
Extension Toxicology Network. 1993. Diquat dibromide. Extension Toxicology Network, U.S. Department of Agriculture. http://pmep.cce.cornell.edu/profiles/extoxnet/dienochlor-glyphosate/diquatext.html

Extension Toxicology Network. 1995. Endothall. Extension Toxicology Network, U.S. Department of Agriculture. http://pmep.cce.cornell.edu/profiles/extoxnet/dienochlor-glyphosate/endothall-ext.html.

Fairchild, G. W. 2004. Ecologically based small pond management. Volume 1: Management strategies for the small pond owner. West Chester University, West Chester, PA.

http://darwin.wcupa.edu:16080/ponds/pondmanage.pdf

Fassett, N. C. 1957. A Manual of Aquatic Plants. The University of Wisconsin Press, Madison, WI.

Hall, T. F. and W. T. Penfound. 1944. The biology of the American Lotus, Nelumbo lutea (Wild.). Am. Midl. Nat. 31:744-758.

Hansson, L. A., H. Anadotter, E. Bergman, S. F. Hamrin, E. Jeppesen, T. Kairesalo, E. Luokkanen, P. A. Nilsson, M. Sondergaard, and J. Strand. 1998. Biomanipulation as an application of food-chain theory: constraints, synthesis, and recommendations for temperate lakes. Ecosystems 1:558-74.

Hopple J. A. and G. D. Foster. 1996. Hydrophobic organochlorine compounds sequestered in submersed aquatic macrophytes [Hydrilla verticillata (L F) Royle] from the tidal Potomac River (USA). Environ. Pollut. 94:39-46.

Hutchinson, G. E. 1975. A Treatise on Limnology: Volume III. Limnological Botany. John Wiley \& Sons, New York, NY.

Kelly, A. 1998. The status of Simazine. Thad Cochran National Warmwater Aquaculture Center Newsletter 1(1):9. http://www.msstate.edu/dept/tenwac/Vol01No1Dec1998.pdf

Lacki, M. J., L. S. Burford, and J. O. Whittaker, Jr. 1995. Food habits of grey bats in Kentucky. J. Mammalogy 76:1256-1259

Lind, C. 2005. Lake and pond treatment by nutrient inactivation. Southern Extension-Research Activity (SERA-17). http://www.sera17.ext.vt.edu/Documents/BMP_lake_and_Pond_Treatment.pdf

Lynch, W. E. 2004. Duckweed and watermeal: prevention and control. Ohio State University Extension Factsheet A-14-04. Ohio State University, Columbus, OH. http://ohioline.osu.edu/a-fact/pdf/0014.pdf

Lovett-Doust, J., L. Lovett-Doust, M. Biernacki, T. K. Mal, and R. Lazar. 1997. Organic contaminants in submersed macrophytes drifting in the Detroit River. Can. J. Fish. Aquat. Sci. 54:2417-2427.

Mackay, D., W. Y. Shiu, J. Billington, and G. L. Huang. 1983. Physical Chemical Properties of Polychlorinated Biphenyls. pp. 59-70. IN Physical Behavior of PCBs in the Great Lakes, D. Mackay, S. Patterson, S. Eisenreich, and M. Simmons, eds. Ann Arbor Science Publishers, Ann Arbor, MI.

Manny, B. A., R. G. Wetzel, and W. C. Johnson. 1975. Annual contribution of carbon, nitrogen, and phosphorus to a hard-water lake by migrant Canada geese. Verh. Internat. Verein. Limnol. 19:949-951. 
Manny, B. A., W. C. Johnson, and R. G. Wetzel. 1994. Nutrient additions by waterfowl to lakes and reservoirs: predicting their effects on productivity and water quality. Hydrobiologia 279/280:121-132.

Masser, M. P., T. R. Murphy, and J. L. Shelton. 2001. Aquatic weed management: herbicides. SRAC Publication No. 361. Southern Regional Aquaculture Center, Stoneville, MS.

http://srac.tamu.edu/tmppdfs/6849756-361fs.pdf

Mehmannavaz, R., S. O. Prasher, and D. Ahmad. 2002. Rhizospheric effects of alfalfa on biotransformation of polychlorinated biphenyls in a contaminated soil augmented with Sinorhizobium meliloti. Process Biochem. 37:955-963.

Mundahl, N. D. 1991. Sediment processing by gizzard shad, Dorosoma cepedianum (Lesueur), in Action Lake, Ohio, USA. J. Fish Biol. 38:565-572

Ohio School of Natural Resources. 1998. Controlling filamentous algae in ponds. A-3-98. Ohio State University, School of Natural Resources, Columbus, OH. http://ohioline.osu.edu/a-fact/0003.html

Otterbine Barebo, Inc. 2003. Integrated pond and lake management manual and guide. Otterbine Barebo, Inc, Emmaus, PA. http://www.otterbine.com/assets/base/resources/PondAndLakeManual.pdf

Petr, T. 2000. Interactions between fish and aquatic macrophytes in inland waters. A review.

FAO Fisheries Technical Paper. No. 396. Rome, FAO. 2000. 185 p.

http://www.fao.org/documents/show_cdr.asp?url_file=/DOCREP/006/X7580E/X7580E03.htm

Peterson, M. J., M. G. Ryon, J. G. Smith, and G. R. Southworth. 2005. Final Report Summarizing 2004

Ecological Studies in Support of the ETTP Site-Wide Remedial Investigation. ORNL/TM-2005/67. Oak Ridge National Laboratory, Oak Ridge, TN. 83 pp.

Poissant, L., C. Beauvais, and M. Pilote. 2003. Mercury gas exchange from aquatic plants. J. de Physique IV 107:1075-1078.

Rich, P. H. and R. G. Wetzel. 1978. Detritus in lake ecosystems. Amer. Nat. 112:57-71.

Richardson, W. L., V. E. Smith, and R. Wethington. 1983, Dynamic Mass Balance of PCB and Suspended Solids in Saginaw Bay - A Case Study. pp. 329-366. IN Physical Behavior of PCBs in the Great Lakes, D. Mackay, S. Patterson, S. Eisenreich, and M. Simmons, eds. Ann Arbor Science Publishers, Ann Arbor, MI.

Ryslava, E., Z. Krejcik, T. Macek, H. Novakova, K. Denmerova, and M. Mackova. 2003. Study of PCB degradation in real contaminated soil. Fresenius Environ. Bull. 12:296-301.

Sculthorpe, C. D. 1985. The Biology of Aquatic Vascular Plants. Koeltz Scientific Books, Königstein, Germany.

Smith, J. G., J. J. Beauchamp, and A. J. Stewart. 2005. An alternative approach for establishing acceptable thresholds on macroinvertebrate community metrics. J. North Am. Benthol. Soc 24:428-440.

Southworth, G. R. 1979. Transport and transformations of anthracene in natural waters. Aquatic Toxicology, ASTM STP 667. pp. 359-380. IN L. L. Marking and R. A. Kimerle, eds. American Society for Testing and Material. 
Stewart, A. J., G. J. Haynes, and M. I. Martinez. 1992. Fate and biological effects of contaminated vegetation in a Tennessee stream. Environ. Toxicol. Chem. 11:653-664.

Stuckey, R. L. 1979. Distribution of Potamogeton crispus (curly pondweed) in North America. Bartonia $46: 22-42$.

Sung, K. J., C. L. Munster, R. Rhykerd, M. C. Drew, and M. Y. Corapcioglu. 2003. The use of vegetation to remediate soil freshly contaminated by recalcitrant contaminants. Water Res. 37:2408-2418.

Suter II, G. W. 1999. Developing conceptual models for complex ecological risk assessments. Hum. Ecol. Risk Assess. 5:375-396.

Thomann, R. V. and J. A. Mueller. 1983. Steady-state modeling of Toxic Chemicals - Theory and Application to PCBs in the Great Lakes and Saginaw Bay. pp. $283-310$. IN Physical Behavior of PCBs in the Great Lakes, D. Mackay, S. Patterson, S. Eisenreich, and M. Simmons, eds. Ann Arbor Science Publishers, Ann Arbor, MI.

Vandiver, V. V. 2002. Biology and control of algae. SS-AGR-34. University of Florida Cooperative Extension Service, Gainesville, FL.

Vanier, C., D. Planas, and M. Sylvestre. 1999. Empirical relationships between polychlorinated biphenyls in sediments and submerged rooted macrophytes. Can. J. Fish. Aquat. Sci. 56:1792-1800.

Wetzel, R. G. 2001. Limnology: Lake and River Ecosystems. Third edition. Academic Press, San Diego, CA.

Wilkinson, S. 2002. The use of lime, gypsum, alum and potassium permanganate in water quality management. Aquaculture Asia 7:12-14.

\section{PCB Fate References}

Abramowicz, D. A., M. J. Brennan, H. M. van Dort, and E. L. Gallagher. 1993. Factors influencing the rate of polychlorinated biphenyl dechlorination in Hudson River sediments. Environ. Sci. Technol. 27:1125-1131.

Bedard, D. L. and M. L. Haberl. 1990. Influence of chlorine substitution pattern on the degradation of polychlorinated-biphenyls by 8 bacterial strains. Microb. Ecol. 20:87-102.

Beurskens, J. E. M., G. A. J. Mol, H. L. Barreveld, B. van Munster, and H. J. Winkels. 1993. Geochronology of priority pollutants in a sedimentation area of the Rhine River. Environ. Toxicol. Chem. 12:1549-1566.

Brenner, R. C., V. S. Magar, J. A. Ickes, E. A. Foote, J. E. Abbott, L. S. Bingler, and E. A. Crecelius. 2004. Long-term recovery of PCB-contaminated sediments at the Sangamo-Weston/Twelvemile Creek/Lake Hartwell Superfund site. Environ. Sci. Technol. 38:2328-2337.

Brown Jr., J. F., R. E. Wagner, D. L. Bedard, M. J. Brennan, J. C. Carnahan, and R. J. May. 1984. PCB transformation in upper Hudson sediments. Northeastern Environ. Sci. 3:167-179. 
Chiarenzelli, J., R. Scrudato, G. Arnold, M. Wunderlich, and D. Rafferty. 1996. Volatilization of polychlorinated biphenyls from sediment during drying at ambient conditions. Chemosphere 33:899-911.

Cho, Y. C., R. C. Sokol, and G. Y. Rhee. 2002. Kinetics of polychlorinated biphenyl dechlorination by Hudson River, New York, USA, sediment microorganisms. Environ. Toxicol. Chem. 21:715-719.

Cho, Y. C., R. C. Sokol, R. C. Frohnhoefer, and G. Y. Rhee. 2003. Reductive dechlorination of polychlorinated biphenyls: Threshold concentration and dechlorination kinetics of individual congeners in Aroclor 1248. Environ. Sci. Technol. 37:5651-5656.

Commoner, B., B. Bush, P. W. Bartlett, K. Couchot, and H. Eisl. 2000. Final Report. The Exposure of the New York City Watershed to PCBs Emitted from the Hudson River. Center for the Biology of Natural Systems, Queens College, CUNY, Flushing, NY.

Connolly, J. P., H. A. Zahakos, J. Benaman, C. K. Ziegler, J. R. Rhea, and K. Russell. 2000. A model of PCB fate in the Upper Hudson River. Environ. Sci. Technol. 34:4076-4087.

Karcher, S. C., M. Small, and J. M. Vanbriesen. 2004. Statistical method to evaluate the occurrence of PCB transformations in river sediments with application to Hudson River data. Environ. Sci. Technol. 38:6760-6766.

Koelmans, A. A., A. van der Heijde, L. M. Knijff, and R. H. Aalderink. 2001. Integrated modeling of eutrophication and organic contaminant fare \& effects in aquatic ecosystems. A review. Wat. Res. 35:3517-3536.

Lake, J. L., R. J. Pruell, and F. A. Osterman. 1992. An examination of dechlorination processes and pathways in New Bedford Harbor sediments. Mar. Envir. Res. 33:502-507, as cited in Sinkkonen and Paasivirta (2000).

Lin, Y., G. Gupta, and J. Baker. 1995. Photodegradation of polychlorinated biphenyl congeners using simulated sunlight and diethylamine. Chemosphere 31:3323-3344.

Magar, V. S., G. W. Johnson, R. C. Brenner, J. F. Quensen III, E. A. Foote, G. Durell, J. A. Ickes, and C. Peven-McCarthy. 2005a. Long-term recovery of PCB-contaminated sediments at the Lake Hartwell Superfund site: PCB dechlorination. 1. End-member characterization. Environ. Sci. Technol. 39:35383547.

Magar, B. S., R. C. Brenner, G. W. Johnson, and J. F. Quensen III. 2005b. Long-term recovery of PCBcontaminated sediments at the Lake Hartwell Superfund site: PCB dechlorination. 2. Rates and extent. Environ. Sci. Technol. 39:3548-3554.

Mousa, M. A., P. E. Ganey, J. F. Quensen III, B. V. Madhukar, K. Chou, J. P. Giesy, L. J. Fischer, and S. A. Boyd. 1998. Altered biologic activities of commercial polychlorinated biphenyl mixtures after microbial reductive dechlorination. Environ. Health Perspec. Suppl. 106:1409-1418.

Pakdeesusuk, U., D. L. Freedman, C. M. Lee, and J. T. Coates. 2003. Reductive dechlorination of polychlorinated biphenyls in sediment from the Twelve Mile Creek arm of Lake Hartwell, South Carolina, USA. Environ. Toxicol. Chem. 22:1214-1220.

Rhee, G.-Y., R. C. Sokol, C. M. Bethoney, Y.-C. Cho, R. C. Frohnhoefer, and T. Erkkila. 2001. Kinetics of polychlorinated biphenyl dechlorination and growth of dechlorinating microorganisms. Environ.

Toxicol. Chem. 20:721-726. 
Schaffner, L. C., R. M. Dickhut, S. Mitra, P. W. Lay, and C. Brouwer-Riel. 1997. Effects of physical chemistry and bioturbation by estuarine macrofauna on the transport of hydrophobic organic contaminants in the benthos. Environ. Sci. Technol. 31:3120-3125.

Sinkkonen, S. and J. Paasivirta. 2000. Degradation half-life times of PCDDs, PCDfs and PCBs for environmental fate modeling. Chemosphere 40:943-949.

Sokol, R. C., C. M. Bethoney, and G. Y. Rhee. 1998. Effect of Aroclor-1248 concentration on the rate and extent of polychlorinated biphenyl dechlorination. Environ. Toxicol. Chem. 17:1922-1926.

Tiedje, J. M., J. F. Quensen III, J. Chee-Sanford, J. P. Schimel, and S. A. Boyd. 1993. Microbial reductive dechlorination of PCBs. Biodegradation 4:231-240.

Wiegel, J. and Q. Wu. 2000. Microbial reductive dehalogenation of polychlorinated biphenyls. FEMS Microbiol. Ecol. 32:1-15.

Zwiernik, M. J., J. F. Quensen III, and S. A. Boyd. 1999. Residual petroleum in sediments reduces the bioavailability and rate of reductive dechlorination of Aroclor 1242. Environ. Sci. Technol. 33:3574-3578. 
APPENDIX A

Validation of Pond Assumptions 



\section{APPENDIX A. Validation of Pond Assumptions}

Table 11. Summary of whether major assumptions regarding current pond conditions were validated by the 2004 summer pond study.

\section{Conditions Hypothesized to Contribute to High Levels of PCBs in P1 Fish}

Assessment of Whether Expected

Conditions Were Validated Based on Summer Pond Study

\section{Fish community assumptions}

- The pond supports high numbers of non-native common carp and/or grass carp

- Shad population numbers are high (due to high algal food sources and open water habitat)

- Relatively high numbers of large and old largemouth bass that feed on shad are present

PCB transport and fate assumptions

- $\mathrm{PCB}$ concentrations in shad are relatively high

- Shad interact with and ingest sediments

- $\quad$ PCB concentrations in bluegill are relatively low

- $\quad$ PCB concentrations in largemouth bass are high

- Storm drain inputs and pond sediments are high in PCBs

- PCB fluxes to Poplar Creek are relatively high
- Verified the presence of both species; common carp were abundant, with highest biomass of four surveyed ponds

- Verified presence of a substantial population of shad, although absolute numbers likely to be under-represented in present survey; highest density of all ponds surveyed

- The K-1007 pond has a substantially higher proportion of large largemouth bass than any of the other ponds in the study

- $\quad$ PCBs were very high in shad ( 20 ppm)

- High concentrations of soil-derived metals in whole shad indicate that they disturb and ingest sediments

- $\quad$ PCB concentrations in bluegill fillets were $<1 \mathrm{ppm}$

- $\quad$ PCBs in large bass were highest of ponds surveyed (4.5 ppm), but lower in 2004 than in previous years, possibly because of an unbalanced shad age/size distribution.

- Caged clams contained up to 4 times higher concentrations of PCBs near outfalls than in pond discharge

- $\quad \mathrm{PCB}$ in clams at pond discharge indicate export to Poplar Creek 
Conditions Hypothesized to Contribute to High Levels of PCBs in P1 Fish
Assessment of Whether Expected

Conditions Were Validated Based on Summer Pond Study

Pond vegetation assumptions

- Submerged and emergent vegetation is near absent in the pond

- Summer conditions promote high suspended algal biomass (and potential DO problems?)

- Surrounding upland vegetation does not provide an adequate buffer to prevent erosion and use by geese

- Verified in 2004 survey

- High summer algal biomass was observed in the 2004 survey; low DO concentrations recorded at some locations

- Mowed lawn adjacent to the ponds was used heavily by geese (Fig 15)

\section{Pond limnological assumptions}

- The pond is comprised of almost all open water habitat (ideal for shad)

- The large portion of the pond is sufficiently shallow to allow for rooted emergent vegetation

- Suspended and flocculent sediment conditions are present

- High nutrient loading is present in the pond due to storm drain (SD) inputs and excessive numbers of geese

- The total acreage of the pond represents the area where fish are available to human or ecological receptors

- Some woody and construction debris noted in pond, but nearly entire acreage was open water habitat and adequate depth for shad

- Approximately a third of the pond was found to be 3 feet or less on the survey dates; see bathymetric survey

- Disturbance of sediments by carp was observed (Figure 15). Soil in the gastrointestinal tracts of gizzard shad indicates re-suspension of sediments by this species

- Phosphorous concentrations are typical of enriched systems

- Lowering the water level will reduce pond surface area substantially (Figs 19 and 20). 
APPENDIX B

Model Run Output 



\section{BASELINE CASE}

Output variables

$\begin{array}{lcc}\text { Total aqueous PCB } & 57.4 & \mathrm{ng} / \mathrm{L} \\ \text { Dissolved PCB } & 11.7 & \mathrm{ng} / \mathrm{L} \\ \text { TSS PCB } & 0.88 & \mathrm{mg} / \mathrm{kg}\end{array}$

Shad, whole

Bluegill fillet

Bluegill whole

Large bass fillet,shad pre Small bass bluegill prey

Bass fillet, bluegill prey
$18.8 \mathrm{mg} / \mathrm{kg}$

$0.8 \mathrm{mg} / \mathrm{kg}$

$6.3 \mathrm{mg} / \mathrm{kg}$

$18.7 \mathrm{mg} / \mathrm{kg}$

$2.3 \mathrm{mg} / \mathrm{kg}$

$6.3 \mathrm{mg} / \mathrm{kg}$
Mass balance

\section{Inputs}

Storm drain

Sediment resuspension

Diffusion from sediment

\section{8 \\ 5}

654

Outputs

Outflow

Volatilization

Particle settling

sum $\quad 654$

Net loss
Turnover and inventory

Inventory in sediments

37360

Turnover time

Inventory in fish years 
STORM DRAIN [PCB] equals $12 \mathrm{ng} / \mathrm{L}$ (versus 250 from clam data)

Output variables

$\begin{array}{lll}\text { Total aqueous PCB } & 50.1 & \mathrm{ng} / \mathrm{L} \\ \text { Dissolved PCB } & 10.2 & \mathrm{ng} / \mathrm{L}\end{array}$

$\begin{array}{lll}\text { Dissolved PCB } & 10.2 & \mathrm{ng} / \mathrm{L} \\ \text { TSS PCB } & 0.77 & \mathrm{mg} / \mathrm{kg}\end{array}$

\section{Shad, whole}

\section{Bluegill fillet}

Bluegill whole

Large bass fillet,shad prey Small bass bluegill prey

Bass fillet, bluegill prey

Small bass fillet shad prey

\section{Mass balance}

\begin{tabular}{lc} 
Inputs & $\mathbf{m g} / \mathbf{d}$ \\
& 5 \\
Storm drain & 561 \\
Sediment resuspension & 5 \\
Diffusion from sediment & \multicolumn{1}{c}{$\quad$ sum } \\
Outputs
\end{tabular}

Volatilization

Particle settling

sum

$5.5 \mathrm{mg} / \mathrm{kg}$

$16.3 \mathrm{mg} / \mathrm{kg}$

$2.0 \mathrm{mg} / \mathrm{kg}$

$\mathrm{mg} / \mathrm{kg}$

$\mathrm{mg} / \mathbf{k g}$

Net loss
Turnover and inventory

$\begin{array}{lcc}\text { Inventory in sediments } & 37360 & \mathrm{~g} \\ \text { Turnover time } & 360 & \text { years } \\ \text { Inventory in fish } & 138 & \mathrm{~g}\end{array}$




\section{ELIMINATION OF BIOTURBATION AND GIZZARD SHAD}

Output variables

$\begin{array}{lcc}\text { Total aqueous PCB } & 8.2 & \mathrm{ng} / \mathrm{L} \\ \text { Dissolved PCB } & 1.7 & \mathrm{ng} / \mathrm{L} \\ \text { TSS PCB } & 0.13 & \mathrm{mg} / \mathrm{kg}\end{array}$

Shad, whole

Bluegill fillet

Bluegill whole

Large bass fillet,shad prey

Small bass bluegill prey

Bass fillet, bluegill prey

Small bass fillet shad prey

$\mathrm{mg} / \mathrm{kg}$

$\mathrm{mg} / \mathrm{kg}$

$\mathrm{mg} / \mathrm{kg}$

$\mathrm{mg} / \mathrm{kg}$

$\mathrm{mg} / \mathrm{kg}$

$\mathrm{mg} / \mathrm{kg}$

\section{Mass balance}

Inputs
Storm drain
Sediment resuspension
Diffusion from sediment

$\mathrm{mg} / \mathrm{c}$

88

Diffusion from sediment

sum

Outputs

Outflow

Volatilization

Particle settling

sum
Turnover and inventory

\section{Inventory in sediments}

37360

g

Turnover time

2208

years 
ELIMINATION OF BIOTURBATION AND GIZZARD SHAD, STORM DRAIN PCB EQUALS 12 NG/L

Output variables

Total aqueous РCB

Dissolved PCB

TSS PCB

$$
\begin{array}{ll}
0.84 & \mathrm{ng} / \mathrm{L} \\
0.17 & \mathrm{ng} / \mathrm{L}
\end{array}
$$$$
0.01 \mathrm{mg} / \mathrm{kg}
$$

Shad, whole

Bluegill fillet

Bluegill whole

Large bass fillet,shad prey

Small bass bluegill prey

Bass fillet, bluegill prey

Small bass fillet shad prey

$0.09 \mathrm{mg} / \mathrm{kg}$

mg/kg

$\mathrm{mg} / \mathrm{kg}$

$\mathrm{mg} / \mathrm{kg}$

$\mathrm{mg} / \mathrm{kg}$

\section{Mass balance}

Inputs
Storm drain
Sediment resuspension

$\mathrm{mg} / \mathrm{d}$

Diffusion

sum

Outputs

\section{Outflow}

Volatilization

Particle settling

sum

\section{Turnover and inventory}

Inventory in sediments

Turnover time

37360

21539 years

Inventory in fish 


\section{LOWER WATER LEVEL 0.5 METERS}

\section{Output variables}

$\begin{array}{lcc}\text { Total aqueous PCB } & 47.8 & \mathrm{ng} / \mathrm{L} \\ \text { Dissolved PCB } & 9.7 & \mathrm{ng} / \mathrm{L} \\ \text { TSS PCB } & 0.73 & \mathrm{mg} / \mathrm{kg}\end{array}$

\section{Shad, whole}

15.6

Bluegill fillet

Bluegill whole

Small bass bluegill prey 1.9

Bass fillet, bluegill prey $\quad 5.2$

Small bass fillet shad prey 5.7

$\mathrm{mg} / \mathrm{kg}$

$\mathbf{m g} / \mathbf{k g}$

$\mathrm{mg} / \mathrm{kg}$

$\mathrm{mg} / \mathrm{kg}$

$\mathrm{mg} / \mathbf{k g}$

\section{Mass balance}

Inputs
Storm drain
Sediment resuspension

$\mathrm{mg} / \mathrm{c}$

sum

Outputs

Outflow

Volatilization

Particle settling

sum
Turnover and inventory

Inventory in sediments

34389

Turnover time

years

Inventory in fish 
ELIMINATION OF BIOTURBATION, COLONIZATION BY MACROPHYTES

Output variables

$\begin{array}{lcc}\text { Total waterborne PCB } & 10.8 & \mathrm{ng} / \mathrm{L} \\ \text { Dissolved PCB } & 2.7 & \mathrm{ng} / \mathrm{L} \\ \text { TSS PCB } & 0.20 & \mathrm{mg} / \mathrm{kg}\end{array}$

* waterborne excludes PCBs on macrophytes

\section{Mass balance}

Inputs

Storm drain

Sediment resuspension

Diffusion from sediment

sum

\section{Outputs}

Outflow

Volatilization

Particle settling

sum

$\begin{array}{ll}0.2 & \mathrm{mg} / \mathrm{kg} \\ 1.4 & \mathrm{mg} / \mathrm{kg}\end{array}$

Bluegill whole

Large bass fillet,shad prey $4.3 \mathrm{mg} / \mathrm{kg}$

Small bass bluegill prey $0.53 \quad \mathrm{mg} / \mathrm{kg}$

Bass fillet, bluegill prey $\quad 1.4 \quad \mathrm{mg} / \mathrm{kg}$

Small bass fillet shad prey $1.6 \mathrm{mg} / \mathrm{kg}$

Net loss
Turnover and inventory

Inventory in sediments

37360

Turnover time

1582

years

Inventory in fish 
ELIMINATION OF BIOTURBATION, COLONIZATION BY MACROPHYTES, STORM DRAIN 12 NG/L PCB

\section{Output variables}

Total waterborne $P C B$

Dissolved PCB

TSS PCB

$\begin{array}{cc}1.1 & \mathrm{ng} / \mathrm{L} \\ 0.3 & \mathrm{ng} / \mathrm{L} \\ 0.02 & \mathrm{mg} / \mathrm{kg}\end{array}$

* waterborne excludes PCBs on macrophytes

$\begin{array}{lcc}\text { Shad, whole } & 0.4 & \mathrm{mg} / \mathrm{kg} \\ & & \\ \text { Bluegill fillet } & 0.0 & \mathrm{mg} / \mathrm{kg} \\ \text { Bluegill whole } & 0.15 & \mathrm{mg} / \mathrm{kg} \\ & & \\ \text { Large bass fillet,shad prey } & 0.4 & \mathrm{mg} / \mathrm{kg} \\ \text { Small bass bluegill prey } & 0.05 & \mathrm{mg} / \mathrm{kg} \\ \text { Bass fillet, bluegill prey } & 0.15 & \mathrm{mg} / \mathrm{kg} \\ \text { Small bass fillet shad prey } & 0.2 & \mathrm{mg} / \mathrm{kg}\end{array}$

$\mathrm{mg} / \mathrm{kg}$

\section{Mass balance}

\section{Inputs}

Storm drain

Sediment resuspension

Diffusion from sediment

$$
\text { sum }
$$

Outputs

Outflow

Volatilization

Particle settling

sum

$\mathbf{m g} / \mathbf{d}$

5
0

5

10

$\overbrace{1}^{\infty}$
Turnover and inventory

Inventory in sediments

37360

15434 years

Net loss

5 
HOT SPOT REMOVAL

Output variables

$\begin{array}{lcc}\text { Total aqueous PCB } & 35.7 & \mathrm{ng} / \mathrm{L} \\ \text { Dissolved PCB } & 7.3 & \mathrm{ng} / \mathrm{L} \\ \text { TSS PCB } & 0.5 & \mathrm{mg} / \mathrm{kg}\end{array}$

$\frac{\infty}{0}$

\begin{tabular}{lcc} 
Shad, whole & 11.7 & $\mathrm{mg} / \mathrm{kg}$ \\
\hline $\begin{array}{l}\text { Bluegill fillet } \\
\text { Bluegill whole }\end{array}$ & 0.5 & $\mathrm{mg} / \mathrm{kg}$ \\
& 3.9 & $\mathrm{mg} / \mathrm{kg}$ \\
\hline $\begin{array}{l}\text { Large bass fillet,shad prey } \\
\text { Small bass bluegill prey }\end{array}$ & 11.6 & $\mathrm{mg} / \mathrm{kg}$ \\
Bass fillet, bluegill prey & 3.9 & $\mathrm{mg} / \mathbf{k g}$ \\
Small bass fillet shad prey & 4.3 & $\mathrm{mg} / \mathrm{kg}$ \\
\hline
\end{tabular}

\section{Mass balance}

\section{Inputs}

Storm drain

Sediment resuspension

Diffusion from sediment

sum

\section{Outputs}

Outflow

Volatilization

Particle settling

sum

$\mathrm{mg} / \mathrm{d}$

88

316

07

407

153

49

204

407

Turnover and inventory

Inventory in sediments

21278

g

Turnover time

288

years 
HOT SPOT REMOVAL, SD=12 ng/L

\section{Output variables}

$\begin{array}{lcc}\text { Total aqueous PCB } & 28.3 & \mathrm{ng} / \mathrm{L} \\ \text { Dissolved PCB } & 5.8 & \mathrm{ng} / \mathrm{L} \\ \text { TSS PCB } & 0.43 & \mathrm{mg} / \mathrm{kg}\end{array}$

\section{Bluegill fillet}

0.4

Bluegill whole

3.1

Large bass fillet,shad prey Small bass bluegill prey

Bass fillet, bluegill prey

Small bass fillet shad prey

$\mathbf{m g} / \mathbf{k g}$

\section{Mass balance}

\begin{tabular}{lc} 
Inputs & $\mathbf{m g} / \mathbf{d}$ \\
& 5 \\
Storm drain & 316 \\
Sediment resuspension & 3 \\
Diffusion from sediment & \\
\multicolumn{1}{c}{ sum } & 323
\end{tabular}

Outputs

Outflow

Volatilization

Particle settling

sum

$\mathrm{mg} / \mathbf{k g}$

$\mathbf{m g} / \mathbf{k g}$

Net loss

122
39
162
323
-156

Turnover and inventory

Inventory in sediments

21277.7

g

Turnover time

363 years

Inventory in fish

78

g 
SEDIMENT REMOVAL WITH [PCB] IN STORM DRAIN EQUALS 250 NG/L

Output variables

Total aqueous PCB

Dissolved PCB

TSS PCB

$\begin{array}{cc}15.6 & \mathrm{ng} / \mathrm{L} \\ 3.2 & \mathrm{ng} / \mathrm{L} \\ 0.24 & \mathrm{mg} / \mathrm{kg}\end{array}$

Shad, whole

Bluegill fillet

Bluegill wr

Large bass fillet,shad prey Small bass bluegill prey

Bass fillet, bluegill prey

Small bass fillet shad prey
$5.1 \mathrm{mg} / \mathrm{kg}$

$0.2 \mathrm{mg} / \mathrm{kg}$

$1.7 \mathrm{mg} / \mathrm{kg}$

$5.1 \mathrm{mg} / \mathrm{kg}$

$0.6 \mathrm{mg} / \mathrm{kg}$

$1.7 \mathrm{mg} / \mathrm{kg}$

$\mathbf{m g} / \mathbf{k g}$

\section{Mass balance}

Inputs

Storm drain

Sediment resuspension

Diffusion from sediment

sum

Outputs

Outflow

Volatilization

Particle settling

sum

Net loss
Turnover and inventory

Inventory in sediments*

* $1 \mathrm{~cm}$ depth

Turnover time

Inventory in fish

Time to accumulate

88 loss

$\begin{array}{lcl}\text { sediment } & 1 & \mathrm{~g} / \mathrm{cm} 3 \\ \text { depth } & 1 & \mathrm{~cm} \\ \text { content } & 10000 \mathrm{~g} / \mathrm{m} 2\end{array}$

$94 \mathrm{~g}$

9 years

$43 \quad 9$

9.1 years 
SEDIMENT REMOVAL WITH [PCB] IN STORM DRAIN EQUALS 12 NG/L

Output variables

Total aqueous PCB

Dissolved PCB

TSS PCB

Shad, whole

Bluegill fillet

Bluegill whole

Large bass fillet,shad prey Small bass bluegill prey

Bass fillet, bluegill prey

Small bass fillet shad prey

$\begin{array}{lc}0.77 & \mathrm{ng} / \mathrm{L} \\ 0.16 & \mathrm{ng} / \mathrm{L} \\ \mathbf{0 . 0 1} & \mathrm{mg} / \mathrm{kg}\end{array}$

0.25

0.01

0.08

0.25

0.03

0.08

0.09

$\mathbf{m g} / \mathbf{k g}$

$\mathrm{mg} / \mathbf{k g}$

$\mathrm{mg} / \mathrm{kg}$

$\mathbf{m g} / \mathbf{k g}$

\section{Mass balance}

Inputs
Storm drain
Sediment resuspension
Diffusion from sediment

$\mathrm{mg} / \mathrm{c}$

Sediment resuspension

Diffusion from sediment

sum

Outputs

Outflow

Volatilization

Particle settling

sum

Net loss
Turnover and inventory

Inventory in sediments

280.2

Turnover time

175 years

Inventory in fish 



\section{INTERNAL DISTRIBUTION}

1. R. A. Efroymson

2. G. K. Jacobs

3. J. M. Loar

4-38. M. J. Peterson

39. M. G. Ryon

40. M. J. Sale

41. J. G. Smith
42. G. R. Southworth

43. A. J. Stewart

44-46. ESD Library

47. ORNL Central Research

48. ORNL Laboratory Records - RC

49. ORNL Laboratory Records - OSTI

\section{EXTERNAL DISTRIBUTION}

50. J. L. Pfeffer, Bechtel Jacobs Company, LLC, P.O. Box 4699, Oak Ridge, TN 37831-7293 